\title{
Ozone stress as a driving force of sesquiterpene emissions: a suggested parameterisation
}

\author{
E. Bourtsoukidis ${ }^{1,2}$, B. Bonn ${ }^{2}$, A. Dittmann ${ }^{2}$, H. Hakola ${ }^{3}$, H. Hellén ${ }^{3}$, and S. Jacobi ${ }^{4}$ \\ ${ }^{1}$ International Max Planck Research School for Atmospheric Chemistry and Physics, Max Planck Institute for Chemistry, \\ 55128 Mainz, Germany \\ ${ }^{2}$ Institute for Atmospheric and Environmental Sciences, J. W. Goethe University, Frankfurt/Main, Germany \\ ${ }^{3}$ Air Quality Laboratories, Finnish Meteorological Institute, P.O. Box 503, 00101 Helsinki, Finland \\ ${ }^{4}$ Hessian Agency for the Environment and Geology, Wiesbaden, Germany
}

Correspondence to: B. Bonn (bonn@iau.uni-frankfurt.de)

Received: 30 April 2012 - Published in Biogeosciences Discuss.: 26 June 2012

Revised: 5 October 2012 - Accepted: 9 October 2012 - Published: 7 November 2012

\begin{abstract}
Sesquiterpenes $\left(\mathrm{C}_{15} \mathrm{H}_{24}\right)$ are semi-volatile organic compounds emitted by vegetation and are of interest in atmospheric research because they influence the oxidative capacity of the atmosphere and contribute to the formation of secondary organic aerosols. However, little is known about their emission pattern and no established parameterisation is available for global emission models. The aim of this study is to investigate a Central European spruce forest and its emission response to meteorological and environmental parameters, looking for a parameterisation that incorporates heat and oxidative stress as the main driving forces of the induced emissions. Therefore, a healthy ca. $80 \mathrm{yr}$ old Norway spruce (Picea abies) tree was selected and a dynamical vegetation enclosure technique was applied from April to November 2011. The emissions clearly responded to temperature changes with small variations in the $\beta$-factor along the year $\left(\beta_{\text {spring }}=0.09 \pm 0.01, \beta_{\text {summer }}=0.12 \pm 0.02\right.$, $\left.\beta_{\text {autumn }}=0.11 \pm 0.02\right)$. However, daily calculated values revealed a vast amount of variability in temperature dependencies $((0.02 \pm 0.002)<\beta<(0.27 \pm 0.04))$ with no distinct seasonality.

By separating the complete dataset in 10 different ozone regimes, we found that in moderately or less polluted atmospheric conditions the main driving force of sesquiterpene emissions is the temperature, but when ambient ozone mixing ratios exceed a critical threshold of $(36.6 \pm 3.9) \mathrm{ppb}_{\mathrm{v}}$, the emissions become primarily correlated with ozone. Considering the complete dataset, cross correlation analysis resulted in highest correlation with ambient ozone mixing ra-
\end{abstract}

tios $\left(\mathrm{CC}_{\mathrm{O}_{3}}=0.63 \pm 0.01 ; \mathrm{CC}_{T}=0.47 \pm 0.02\right.$ at $t=0 \mathrm{~h}$ for temperature) with a time shift $2-4 \mathrm{~h}$ prior to the emissions. An only temperature dependent algorithm was found to substantially underestimate the induced emissions $(20 \%$ of the measured; $R^{2}=0.31$ ). However, the addition of an ozone dependent term improved substantially the fitting between measured and modelled emissions ( $81 \%$ of the modelled emissions could be explained by the measurements; $R^{2}=0.63$ ), providing confidence about the reliability of the suggested parameterisation for the spruce forest site investigated.

\section{Introduction}

Biogenic volatile organic compounds (BVOCs), including monoterpenes (MT), sesquiterpenes (SQT), isoprene and oxygenated VOCs, are reactive plant compounds emitted into the atmosphere (Kesselmeier et al., 1999). They have been hypothesized to protect plants from oxidative damage under elevated concentrations of reactive oxygen species (Vickers et al., 2009). Especially SQT, react readily with atmospheric ozone, with a high potential to form secondary organic aerosol (Hoffmann et al., 1997; Jaoui et al., 2003; Bonn et al., 2008). Their vital role on atmospheric chemistry is stressed out by their ability to influence the oxidative capacity of the atmosphere (Fuentes et al., 2000) and their contribution to secondary organic aerosol production (Hoffmann et al., 1997; Andreae and Crutzen, 1997; Bonn et al., 2003; Kulmala et al., 2004). In order to understand the role of BVOCs 
in atmospheric chemistry, it is important to quantify their emissions and atmospheric abundance, along with a better understanding of their atmospheric oxidation.

SQT belong to a broad spectrum of VOCs emitted by plant leaves that typically act in multiple roles for plant protection (Niinemets et al., 2004). However, the mechanism by which volatile isoprenoids (isoprene, MT, SQT) protect plants against oxidative stress and probably against a wide range of environmental stresses is still under investigation. In a recent study, Jardine et al. (2012) highlighted the potential function of isoprene production, in protecting plants against reactive oxygen species. Global and regional atmospheric chemistry models typically incorporate empirical algorithms that have been developed to model VOC emission rates and their dependence on photosynthetic active radiation and leaf temperature (Guenther et al., 1995, 2000, 2006), with an exponential relationship between emission rates and leaf temperature. Nevertheless, strong variations of standard emission factors of many plant species with discrepancies of up to an order of magnitude have been reported (Kesselmeier and Staudt, 1999; Niinemets et al., 2011). Filella et al. (2007) concluded that algorithms which use only incident irradiance and leaf temperature as drivers to predict VOC emission rates may be inadequate. As the review of Holopainen and Gershenzon (2010) has shown, the interaction of multiples stresses, both biotic and abiotic, provides a great potential to alter VOC emission. It is most likely that other environmental factors such as drought, ozone and $\mathrm{CO}_{2}$ concentrations can amplify or attenuate such alterations in the emission responses to temperature and light (Staudt et al., 2011).

The phytotoxicity of ozone has been demonstrated for forest tree species since more than $50 \mathrm{yr}$ (Karnosky et al., 2007 and references cited therein). Current evidence suggests that several global change drivers such as ozone concentration can also affect both constitutive and herbivoreinduced BVOCs production (Loreto et al., 2007; Vuorinen et al., 2005; Blande et al., 2007). Ozone causes biochemical and physiological changes leading to the inhibition of photosynthesis and a consequent decrease in plant growth (Guderian et al., 1985), often associated with visible injuries (Loreto et al., 2001; Vollenweider and Gunthardt-Georg, 2005). Plants act as a sink for ozone, through stomatal and non-stomatal processes (Fares et al., 2010) while ozone may apparently induce biosynthesis and emission of volatile isoprenoids, even in plants that do not naturally emit these compounds (Heiden et al., 1999). In the presence of $\mathrm{NO}_{\mathrm{x}}$, however, these BVOCs initiate reactions that lead to ozone formation (Fehsenfeld et al., 1992; Kurpius and Goldstein, 2003). Hence, the dual action of VOCs is depending on the presence of atmospheric pollutants (Loreto and Schnitzler, 2010). The chemical reactivity of atmospheric terpenes led to the hypothesis that volatile terpenes play a similar dual action inside the leaves before they are released into the atmosphere (Hewitt et al., 1990; Loreto et al., 2001; Jardine et al., 2012). Vegetation is exposed to increasing levels of tropospheric ozone concen- trations, particularly in northern mid-latitudes (Brasseur et al., 1998; Parrish et al., 2009). Usually forests considered to be low level ozone regions due to the excessive sink terms. However, because of the urban areas at the vicinity of the site of interest, highly elevated ozone concentrations are observed during the season. This pollutant penetrates in leaves through stomata and quickly reacts inside leaves, thus, making plants valuable ozone sinks, but at the same time triggers oxidation processes which lead to leaf injuries (Fares et al., 2010). Therefore, atmospheric interactions of ozone and other oxidants with biogenic VOCs appears to be quite complex, especially in forest ecosystems.

In their review, Peñuelas and Staudt (2010) reported a significant amount of results that indicate an elevated sum of SQT and MT emissions under ozone stress. However, SQT emissions were treated to date as only temperature driven, with slightly higher temperature dependency from MT. To date, aerosol model studies include only MTs as the biogenic precursor for organic aerosol (Carslaw et al., 2010) since no similar emission record is available for SQT (Duhl et al., 2008).

According to Jardine at al. (2011), only a few studies have attempted to quantify ambient SQT concentrations (Hakola et al., 2006; Bonn et al., 2007; Bouvier-Brown et al., 2009; Boy et al., 2008; Kim et al., 2009, 2010) including the attempt of Kim et al. (2009) to quantify ecosystem-scale SQT emission rates using the vertical gradient technique. Nevertheless, the necessity for further experimental data (see Hakola et al., 2006; Tarvainen et al., 2005, 2007 with remarks) and the need for a parameterisation which includes further environmental factors (Loreto et al., 2004; Staudt et al., 2011), is apparent. According to Loreto et al. (2004) and to Holopainen and Gerhenson (2010), only the study of plant volatile emission under realistic, multiple stress regimes will be able to determine the natural occurrence of such VOC reaction products and their importance in plant function. This study provides on-line seasonal measurements of SQT emissions from a spruce tree into the atmosphere, under a variety of stress regimes and attempts to combine temperature and ozone stress in a single parameterisation that can be used for future model calculations.

\section{Material and methods}

\subsection{Site description}

Biogenic emissions were investigated from a $(13 \pm 1) \mathrm{m}$ tall, healthy Norway spruce (Picea abies) tree, located at Taunus Observatory $\left(50^{\circ} 13^{\prime} \mathrm{N}, 8^{\circ} 26^{\prime} \mathrm{E}\right.$ and $825 \mathrm{~m}$ a.s.l.), at the top of Mt. Kleiner Feldberg; a hill on the Taunus ridge in southwestern Germany (Crowley et al., 2010). The area around the observatory is covered by a coniferous forest, in which Norway spruce is the dominant tree type with smaller contributions of pine. The area up to $100 \mathrm{~km}$ to the North of Kleiner 
Feldberg is only lightly populated and is devoid of major industry. However, Taunus lies on the northern rim of the relatively heavily industrialised Rhine-Main region. The remote character of the site is influenced mainly by south-easterly winds, where the city of Frankfurt and the Rhine-Main-area including airport and major traffic pathways are located. The wind pattern can result in very high ozone concentrations, providing a variety of atmospheric conditions that the forest ecosystem is experiencing.

\subsection{Experimental setup}

Emission data were obtained using a branch enclosure technique, applied for a healthy branch five metres above ground level. The measurements took place from 8 April to 11 November 2011. The instrumentation was kept inside a monitoring van, situated below the investigated tree. VOCs were measured by a PTR-MS (Proton Transfer Reaction Mass Spectrometer), while samples have also been analysed with GC-MS (Gas Chromatography - Mass Spectrometry) techniques for identification of individual VOCs. Temperature, relative humidity, ozone $\left(\mathrm{O}_{3}\right)$ and photosynthetic active radiation (PAR, for September onward only) were continuously measured inside the plant cuvette. Therefore, a temperature-humidity sensor (Hygrosens Instruments), an ozone analyser (model APOA-350E, Horiba) and two (inside and outside the cuvette) PAR sensors (LI-190SZ, LI190SL/Li-Cor Inc., Lincoln, NB, USA) have been applied. Meteorological and environmental parameters (radiation, atmospheric pressure, wind velocity and direction, temperature, $\mathrm{O}_{3}$, relative humidity, soil moisture, precipitation, global radiation, $\mathrm{H}_{2} \mathrm{O}, \mathrm{NO}, \mathrm{NO}_{2}$ ) were measured by HLUG (Hessian Agency for Environment and Geology) and DWD (German Weather Service), $50 \mathrm{~m}$ away from the measuring site.

The dynamic branch enclosure was a cylindrical shaped glass cuvette (volume $=151$ ), with a lid that can be opened and closed by an electrical compressor. During closure, air was drawn from the chambers to the analysers along the sampling lines and the under-pressure was avoided with replacement by ambient air at equal flow rate (Ruuskanen et al., 2005). The contact between plant surface and the chamber was avoided when possible, while a fan was installed to ensure homogenous mixing of the air in the enclosure. Interaction with ozone and other gases were studied in order to quantify possible interferences with the enclosure. Ozone did not show to react with the cuvette's wall while VOCs were corrected for deposition. During June (DOY $=167$ ), the first selected branch showed visible damage in the bark after a storm event and strong winds prevailing at the site of interest. For avoiding different stress responses, another branch close to the selected one was used for the continuation of the experiments. During October $(\mathrm{DOY}=283)$ a type of fungi started to develop on the enclosed branch and a third one was selected. All the data up to 3 days after the newly se- lected branches were excluded from the data analysis. The quantified PAR losses due to the cuvette material range from 25 to $45 \%$, depending on the solar zenith angle.

\subsection{PTR-MS measurements}

Volume mixing ratios of total MT and total SQT were quantified using a commercial high-sensitivity proton transfer reaction-mass spectrometer (PTR-MS, IONICON, Austria). General information for the analytical technique can be found in Blake et al. (2009) and references therein. The PTR-MS was operated in standard conditions with a drift tube voltage of $600 \mathrm{~V}$ and drift tube pressure of $2.3 \mathrm{mbar}$ $\left(E / N=117 \mathrm{Td} ; E\right.$ is the electric field strength in $\mathrm{V} \mathrm{cm}^{-1}, N$ is the buffer gas number density in units of $\mathrm{cm}^{-3}, 1 \mathrm{Td}=1$ Townsend $10^{-17} \mathrm{~cm}^{2} \mathrm{~V}^{-1}$ ). Optimization of PTR-MS conditions resulted in extremely high and sustained primary ion signal $\left(\mathrm{H}_{3} \mathrm{O}^{+}=4-7 \times 10^{7} \mathrm{cps}\right)$. The ion source conditions were such that the contribution of $\mathrm{O}_{2}^{+}$impurity ions (the major impurity ions) relative to the sum of proton hydrates at standard drift tube voltage $(600 \mathrm{~V})$ was limited to $2 \%$. Dhooghe et al. (2008) showed that $\mathrm{O}_{2}^{+}$ions react equally fast with sesquiterpenes as do $\mathrm{H}_{3} \mathrm{O}^{+}$ions, so the contribution of product ions originating from $\mathrm{O}_{2}^{+} /$sesquiterpene reactions to the sum of all sesquiterpene product ions observed in the mass spectra will, therefore, not exceed $2 \%$. The dwell time for MT $(m / z=137)$ was adjusted to $2 \mathrm{~s}$, while the dwell time for SQT $(m / z=205)$ was adjusted to $20 \mathrm{~s}$ for further increase in the detection efficiency.

The PTR-MS instrument was frequently calibrated with a gas standard (L4763, Ionimed analytic GmbH, Austria). For SQT, calibrations were performed with a permeation oven technique and a $\beta$-caryophyllene standard (W225207, Sigma-Aldrich, Inc.). The experimental determined reaction rate constant for MT was $1.8-2.2 \times 10^{-9}$ molecule $\mathrm{cm}^{3} \mathrm{~s}^{-1}$ $\left(2.5 \times 10^{-9}\right.$ molecule $\mathrm{cm}^{3} \mathrm{~s}^{-1}$; Zhao and Zhang, 2004) and for SQT $2.5-2.9 \times 10^{-9}$ molecule $\mathrm{cm}^{3} \mathrm{~s}^{-1}\left(3.0 \times 10^{-9}\right.$ molecule $\mathrm{cm}^{3} \mathrm{~s}^{-1}$; Dhooghe et al., 2008; Kim et al., 2010). Reaction of $\mathrm{H}_{3} \mathrm{O}^{+}$ions with many VOCs mainly results in the protonated VOC, but the $\mathrm{H}_{3} \mathrm{O}^{+}$/sesquiterpene interaction in a PTR-MS reactor at typical drift-tube conditions is known to proceed through both dissociative and non-dissociative proton transfer, resulting in multiple fragment ion species. This fragmentation results in a decrease of the detection efficiency with respect to other VOCs, which are not or hardly subjected to fragmentation following protonation (Dhoogle et al., 2008). The PTR-MS technique has already been applied for the detection of sesquiterpenes on several occasions and expected product ions and their relative abundances have been reported for some sesquiterpenes at standard PTR-MS conditions (Ezra et al., 2004; Lee et al., 2006; Demarcke et al., 2009; Kim et al., 2009, 2010). The relative abundance of parent SQT ion signal quantified as $32 \pm 2 \%$ and comes in line with the previous values reported. According to Kim et 
al. (2009) when only $m / z 205^{+}$is considered, the uncertainty increases to $30 \%$.

Another major issue when measuring SQT are transfer line (tube) losses. For minimising this effect the tube that was transferring the air to the instruments was manufactured from glass (inner diameter $=3 \mathrm{~mm}$, total length $=4.1 \mathrm{~m}$ ) and heated up to $70^{\circ} \mathrm{C}$. Glass is an inert material that reduces memory effects due to BVOC adsorption/desorption on surfaces and was found to be the favourite of all materials tested for SQT measurements (Helmig et al., 2003). Tubing losses were quantified prior to the measurements $((9 \pm 1) \%$ for SQT, $(7 \pm 1) \%$ for MT) in the laboratory, using a $\beta$-caryophyllene (W225207, Sigma-Aldrich, Inc.) and $\alpha$-pinene (L4763, Ionimed analytic $\mathrm{GmbH}$ ) standards. The flow rate was continuously maintained at $1.81 \mathrm{~min}^{-1}$, resulting in a very short total residence time in the line downstream of the enclosure $(2.2 \mathrm{~s})$.

\subsection{Emission calculation}

As reported before, the dynamic enclosure was automatically operated with an electrical compressor. The chamber remained open for the most of the time and was closing three times per hour. Closing time adjusted to be $3 \mathrm{~min}$ in a 20 min cycle. The mass to charge ratios $(\mathrm{m} / \mathrm{z})$ that were continuously monitored during a PTR-MS cycle were: 21 $\left(\mathrm{H}_{3} \mathrm{O}^{+}\right), 30\left(\mathrm{NO}^{+}\right), 32\left(\mathrm{O}_{2}^{+}\right), 37\left(\mathrm{H}_{2} \mathrm{O}-\mathrm{H}_{3} \mathrm{O}^{+}\right)$with a dwell time of $50 \mathrm{~ms}$ each. For the purposes of this study $\mathrm{m} / \mathrm{z}$ ratios of $137\left(\mathrm{MT}^{+} \mathrm{H}^{+}\right), 81$ (major MT fragment), 205 (SQT$\mathrm{H}^{+}$) and 149 (major SQT fragment) were monitored with the aforementioned dwell times of $2 \mathrm{~s}$ for the parent ion mass of MT $(m / z=137)$ and $20 \mathrm{~s}$ for the parent ion mass of SQT $(m / z=205)$. The time resolution of one PTR-MS measurement was $36 \mathrm{~s}$, resulting in five measurements during a single closed cuvette period. This facilitates a linear fit to the mixing ratios measured, in order to obtain the mean emission during the closure period.

Enclosure approaches "cannot be used to estimate emission rates without the exclusion or corrections of ozone and disturbance effects during the studies" (Jardine et al., 2011). In order to correct for ozone destruction during the sampling process, selected branch emissions were studied by GC-MS technique at the Finnish Meteorological Institute in Helsinki and compared with the chemical analysis performed earlier at Mainz University (Münz, 2010) for the site of interest. The VOC samples for GC-MS analysis performed at the Finnish Meteorological Institute in Helsinki, were collected from branch enclosures (101 Tedlar bags) on adsorbent tubes filled with Tenax-TA and Carbopack-B. Emissions from three different branches ( 2 during spring and one during autumn) were studied. The samples were analysed in the laboratory, using a thermal desorption instrument (PerkinElmer TurboMatrix 650, Waltham, USA) attached to a gaschromatograph (Perkin-Elmer Clarus 600, Waltham, USA) with DB-5MS (60 m, $0.25 \mathrm{~mm}, 1 \mu \mathrm{m})$ column and a mass se- lective detector (Perkin-Elmer Clarus 600T, Waltham, USA). The system was calibrated using liquid standards injected on Tenax TA-Carbopack B adsorbent tubes and analysed together with the samples. More detailed description on GCMS analysis can be found from Hellén et al. (2012) and from Münz (2010). Both measurement methods revealed the presence of $\beta$-caroyphyllene, $\alpha$-farnesene, longicyclene and $\alpha$-humulene while the method applied at the Finnish Meteorological Institute additionally found aromadendrene and longipinene. These values might vary at maximum by $\pm 10 \%$ along the year, but due limited amount of samples analysed, a clear conclusion about the relative abundances along the season cannot be driven.

Ozonolysis reaction rate constants were calculated based on these results. On average MT consisted of $28 \% \beta$-pinene, $25.2 \% \alpha$-pinene, $17.5 \%$ limonene, $14.2 \% \beta$-phellandrene, $9.3 \%$ camphene and $5.8 \%$ myrcene, while SQT were treated as $35 \% \beta$-caryophyllene, $29 \% \alpha$-farnesene, $11 \%$ aromadendrene, $18 \%$ longicyclene, $3 \% \alpha$-humulene and traces of $\beta$-farnesene and longipinene. Note that the fraction of $\beta$ caryophyllene included longifolene as well, which could not be separated. Based on the work of Münz (2010) this is mainly $\beta$-caryophyllene and, therefore, was treated as such for further analysis. The above approach resulted in the two following mean reaction rate coefficients with respect to ozone: $k_{\mathrm{SQT}+\mathrm{O}_{3}}=(6.6 \pm 2.1) \times 10^{-15} \mathrm{~cm}^{3}$ molecule $^{-1} \mathrm{~s}^{-1}$; $k_{\mathrm{MT}+\mathrm{O}_{3}}=(9.4 \pm 0.9) \times 10^{-17} \mathrm{~cm}^{3}$ molecule $\mathrm{s}^{-1} \mathrm{~s}^{-1}$. Since several of the SQT-ozone reaction rates are not well known, the uncertainty range is, therefore, increased.

In a review of SQT emissions from vegetation, $\beta$ caryophyllene was found to be the most frequently reported SQT emitted and the most abundant SQT within many emission profiles (Duhl et al., 2008). Ozonolysis rate constant for $\beta$-caryophyllene is $1.16 \times 10^{-14} \mathrm{~cm}^{3}$ molecule ${ }^{-1} \mathrm{~s}^{-1}$ (Shu and Atkinson, 1994) and while several SQTs have high reported ozonolysis rate constants similar to $\beta$-caryophyllene (e.g., $\alpha$-humulene, $1.2 \times 10^{-14} \mathrm{~cm}^{3}$ molecule ${ }^{-1} \mathrm{~s}^{-1}$ ), others are nearly two orders of magnitude lower if sterically hindered (e.g., $\alpha$-copaene, $1.6 \times 10^{-16} \mathrm{~cm}^{3}$ molecule $^{-1} \mathrm{~s}^{-1}$ ) (Shu and Atkinson, 1994). The ozonolysis rate constant that is used for all SQT has been reported to be $3.3 \times 10^{-15} \mathrm{~cm}^{3}$ molecule $\mathrm{e}^{-1} \mathrm{~s}^{-1}$ (Bouvier-Brown et al., 2008) and is in the same order of magnitude, but smaller than the one applied in this study because of the different SQT mixture found. Sensitivity tests on the ozonolysis rate constant did not show any substantial deviations on the calculated emissions. The upper and lower possible reaction rates would have resulted in a change on the measured emissions by only $\pm(17.3-$ 6.1) $\mathrm{ng} g(\mathrm{dw})^{-1} \mathrm{~h}^{-1}$ on average.

Based on the above approach, the measured data were corrected for ozone reaction losses by considering the individual reaction rate constants for the aforementioned SQT, weightened by their individual contribution to the emissions. Further corrections have been applied for deposition $\left(k_{\text {dep }}=(2.64 \pm 0.23) \times 10^{-5} \mathrm{~s}^{-1}\right)$ and dilution 
$\left(k_{\text {dil }}=(2.9 \pm 0.2) \times 10^{-3} \mathrm{~s}^{-1}\right)$ losses for both compounds. Deposition rates were calculated by the exponential decline in a closed cuvette for a three day period (no sources), while dilution rates were calculated considering the total flow that was drawn from the chambers to the analysers and, as mentioned before, was replaced with ambient air at equal flow rate. The last data points with open cuvette were used to quantify the ambient mixing ratios of total MT and SQT. With respect to the corrections, the deposition and ozone loss rate had a minor impact on MT concentrations, indicating that the dilution is the major loss factor. For SQT, however, the situation was different with the ozone reactions to be the dominating loss procedure while the deposition and dilution losses were substantially smaller. The general pattern assumed to apply for the entire season and possible changes in individual contribution would induce further uncertainties that would not, however, impact on the measured by PTRMS total SQT concentrations in a critical way.

In summary, the emissions rates were calculated using the mass balance equation similar to the literature (i.e., Hakola et al., 2006), but with the addition of the aforementioned corrections:

$E=F \cdot \frac{\left|C_{i+1} \cdot \exp \left(k_{\mathrm{dil}}+k_{\mathrm{SQT}} \cdot\left[\mathrm{O}_{3}\right]+k_{\mathrm{dep}}\right) \cdot \Delta t-C_{i}\right|}{m}$

Here, $F$ is the flow rate through the chamber, $C_{i}$ is the concentration one the last measuring step before the cuvette closes, $C_{i+1}$ is the next measurement corrected for dilution $\left(k_{\mathrm{dil}}\right)$, ozone reaction losses $\left(k_{\mathrm{SQT}} \times\left[\mathrm{O}_{3}\right]\right)$ and deposition on the cuvette walls $\left(k_{\mathrm{dep}}\right)$. As $\Delta t$ is defined the time interval between two continuous measurements while $m$ is the dry biomass of the enclosed branch. Biogenic emissions are usually quantified in $n g g(d w)^{-1} h^{-1}$, where $g(d w)$ is the needle dry weight mass in g. After the experiments, the branch was cut and the needles were dried in order to measure their mass. During the growing period, frequent length measurements were conducted and the dry biomass was extrapolated from these measurements. The data up to $2 \mathrm{~h}$ after any length measurement were excluded because of the observed stress response of touching the branch.

\section{Results}

\subsection{Driving forces}

Under natural conditions, plants rarely experience single stress factors one by one, but are much more likely to be exposed to multiple stresses simultaneously. The role of volatiles in protection against thermal stress has been relatively well studied, while ozone was found to trigger the emissions of herbivore induced plant volatiles (Vuorinen at al., 2004) under controlled laboratory experiments. Light and drought stress have been considered as environmental factors that can also influence biogenic emissions. At this section, we present the effects that these parameters can have in SQT emissions. In a peculiar season, which was characterised by a warm and moderately dry spring (precipitation anomaly $<25 \%$; DWD), a wet summer (precipitation anomaly 126$150 \%$; DWD) and an extremely dry autumn (precipitation anomaly $<50 \%$; DWD), SQT emissions were analysed and studied in order to discern the importance of different driving forces.

\subsubsection{Temperature effect}

SQT emissions clearly responded to temperature changes. The analysis of emission rates as a function of temperature was performed similar to Guenther et al. (1995), as exponential function between temperature and SQT emissions:

$E_{\mathrm{SQT}, T}=E_{\mathrm{S}(T)} \cdot \exp \left(\beta \cdot\left(T-T_{\mathrm{S}}\right)\right)$

Here, $E_{\mathrm{SQT}, T}$ is the emission rate (in $\mathrm{ng} \mathrm{g}(\mathrm{dw})^{-1} \mathrm{~h}^{-1}$ ) observed at temperature $T . E_{\mathrm{s}(T)}$ is the standard emission potential at $T_{\mathrm{s}}=30^{\circ} \mathrm{C}$ (Guenther et al., 1995) and $\beta\left({ }^{\circ} \mathrm{C}^{-1}\right.$ ) is an empirical coefficient called $\beta$-factor, that is based on the best fit curve between temperature and emission rate. We have to emphasise that even if the surface temperature $\left(T_{\mathrm{S}}\right)$ might differ by $1-2{ }^{\circ} \mathrm{C}$ from the enclosure temperature, we kept the formulation similar to the literature (e.g., Duhl et al., 2008). Finally, $T\left({ }^{\circ} \mathrm{C}\right)$ is the temperature inside the cuvette that on average was about one degree Celsius above ambient temperature. Applying our data to the above equation, we derived the standard emission potential $\left(E_{\mathrm{s}(T)}=(347.2 \pm 70.4) \mathrm{ng} \mathrm{g}(\mathrm{dw})^{-1} \mathrm{~h}^{-1}\right)$ and the $\beta$-factor $\left.(\beta=0.11 \pm 0.02)^{\circ} \mathrm{C}^{-1}\right)$.

The two unknown terms were calculated by the exponential fitting between temperature and SQT emissions. As it is demonstrated in Fig. 1a, SQT emissions rise exponentially with the temperature, but with varying temperature dependency (slope $=\beta$-factor) and standardised emission potential at $30^{\circ} \mathrm{C}\left(E_{\mathrm{s}}\right)$ during the year. The emission potential was found to be highest during spring $\left(E_{\mathrm{s}(T) \text {,spring }}=(533.8 \pm 61.7) \mathrm{ng} \mathrm{g}(\mathrm{dw})^{-1} \mathrm{~h}^{-1}\right)$ and declined during summer and autumn $(352.9 \pm 56.1)$ and $(175.9 \pm 23.7) \mathrm{ng} g(\mathrm{dw})^{-1} \mathrm{~h}^{-1}$, respectively), with the latest values to be thrice lower than the spring ones. On contrary, seasonal calculated $\beta$-factors showed similar behaviour during the season. Slightly higher values observed during summer $\left(\beta_{\text {summer }}=(0.12 \pm 0.02)^{\circ} \mathrm{C}^{-1}\right)$, followed by autumn ones $\left(\beta_{\text {autumn }}=(0.11 \pm 0.02)^{\circ} \mathrm{C}^{-1}\right)$. Temperature dependency found to be minimum during spring time $\left(\beta_{\text {spring }}=(0.09 \pm 0.01)^{\circ} \mathrm{C}^{-1}\right)$, mainly because of the low $\beta$ factors observed during May (Fig. 2), where a severe draught stress was present and possibly the tree was not able to extract water of the soil anymore, closing its stomata to prevent further water loss.

The exponential relationship between emissions and temperature has been used to describe MT emissions during the last two decades (Guenther et al., 1993) while recent 

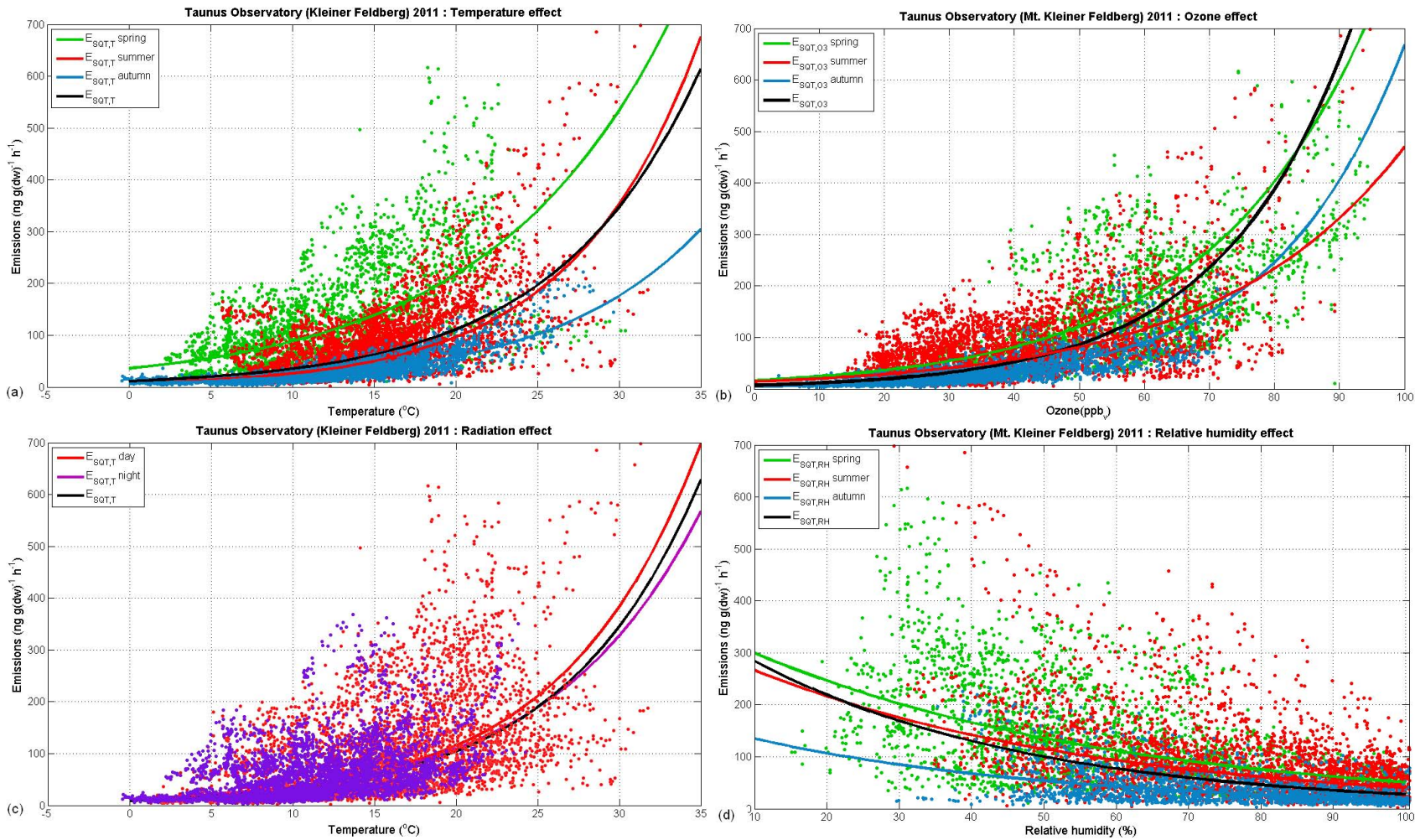

Fig. 1. SQT emission responses to different stress factors. (a) (temperature): $E_{\mathrm{SQT}, T}=(347.2 \pm 70.4) \quad \mathrm{ng} \mathrm{g}(\mathrm{dw})^{-1} \mathrm{~h}^{-1}$ $\exp \left((0.11 \pm 0.02)^{\circ} \mathrm{C}^{-1} \cdot\left(T-30^{\circ} \mathrm{C}\right)\right), \quad E_{\mathrm{SQT}, T} \quad($ spring $)=(533.8 \pm 61.7) \quad \mathrm{ng}(\mathrm{dw})^{-1} \mathrm{~h}^{-1} \cdot \exp \left((0.09 \pm 0.01) \quad{ }^{\circ} \mathrm{C}^{-1} \cdot\left(T-30^{\circ} \mathrm{C}\right)\right)$, $E_{\mathrm{SQT}, T}$ (summer) $=(352.9 \pm 56.1) \mathrm{ng} \mathrm{g}(\mathrm{dw})^{-1} \mathrm{~h}^{-1} \cdot \exp \left((0.12 \pm 0.02){ }^{\circ} \mathrm{C}^{-1} \cdot\left(T-30^{\circ} \mathrm{C}\right)\right), E_{\mathrm{SQT}, T}($ autumn $)=(175.5 \pm 61.7)$ $\mathrm{ng} g(\mathrm{dw})^{-1} \mathrm{~h}^{-1} \cdot \exp \left((0.11 \pm 0.02){ }^{\circ} \mathrm{C}^{-1} \cdot\left(T-30^{\circ} \mathrm{C}\right)\right)$. (b) (ozone): $E_{\mathrm{SQT}, \mathrm{O}_{3}}=(7.1 \pm 1.3) \operatorname{ngg}(\mathrm{dw})^{-1} \mathrm{~h}^{-1} \cdot \exp ((0.05 \pm 0.01)$ $\left.\mathrm{ppb}_{\mathrm{v}}^{-1} \cdot\left[\mathrm{O}_{3}\right]\right), E_{\mathrm{SQT}_{\mathrm{O}}}$ (spring) $=(16.4 \pm 1.9) \mathrm{ngg}(\mathrm{dw})^{-1} \mathrm{~h}^{-1} \cdot \exp \left((0.04 \pm 0.01) \mathrm{ppb}_{\mathrm{v}}^{-1} \cdot\left[\mathrm{O}_{3}\right]\right), E_{\mathrm{SQT}, \mathrm{O}_{3}}$ (summer) $=(14.2 \pm 3.1)$

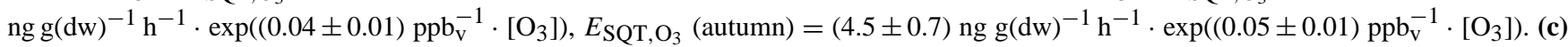
(radiation): $E_{\mathrm{SQT}, T}($ day $)=(365.1 \pm 77.1) \mathrm{ngg}(\mathrm{dw})^{-1} \mathrm{~h}^{-1} \cdot \exp \left((0.12 \pm 0.02)^{\circ} \mathrm{C}^{-1} \cdot\left(T-30{ }^{\circ} \mathrm{C}\right)\right), E_{\mathrm{SQT}, T}(\mathrm{night})=(327 \pm 57.4) \mathrm{ng}$ $\mathrm{g}(\mathrm{dw})^{-1} \mathrm{~h}^{-1} \cdot \exp \left((0.11 \pm 0.02)^{\circ} \mathrm{C}^{-1} \cdot\left(T-30^{\circ} \mathrm{C}\right)\right)$. (d) (rel. humidity): $E_{\mathrm{SQT}, \mathrm{RH}}=(409.1 \pm 84.1) \mathrm{ng} \mathrm{g}(\mathrm{dw})^{-1} \mathrm{~h}^{-1} \cdot \exp (-(0.03 \pm 0.01) \cdot$ $\mathrm{RH}[\%]), E_{\mathrm{SQT}, \mathrm{RH}}$ (spring) $=(355.2 \pm 45.2) \mathrm{ng} \mathrm{g}(\mathrm{dw})^{-1} \mathrm{~h}^{-1} \cdot \exp (-(0.02 \pm 0.01) \cdot \mathrm{RH}[\%]), E_{\mathrm{SQT}, \mathrm{RH}}($ summer $)=(338.9 \pm 62.7) \mathrm{ng}$ $\mathrm{g}(\mathrm{dw})^{-1} \mathrm{~h}^{-1} \cdot \exp (-(0.02 \pm 0.01) \cdot \mathrm{RH}[\%]), E_{\mathrm{SQT}, \mathrm{RH}}($ autumn $)=(163.9 \pm 31.8) \mathrm{ng} \mathrm{g}(\mathrm{dw})^{-1} \mathrm{~h}^{-1} \cdot \exp (-(0.02 \pm 0.01) \cdot \mathrm{RH}[\%])$.

reports (Tarvainen et al., 2005; Helmig et al., 2006, 2007; Hakola et al., 2006) have shown SQT with slightly stronger temperature dependence than MT. For this particular site MT emissions were correlated with the enclosure temperature and the derived emission potential and $\beta$-factor were $(885.5 \pm 149.6) \mathrm{ng} \mathrm{g}(\mathrm{dw})^{-1} \mathrm{~h}^{-1}$ and $(0.11 \pm 0.02)^{\circ} \mathrm{C}^{-1}$ accordingly.

The basal emission potential $E_{\mathrm{M}}(T)$ was substantially higher for MT, but the $\beta$-factor was identical with the one for SQT, when using the complete dataset. As it is shown in Sect. 3.4, the $\beta$-factor is influenced by ambient ozone concentrations, but only in the case of SQT.

\subsubsection{Oxidative stress}

Ambient ozone concentrations varied during the season notably, proving a wide range of oxidative stress that the ecosystem experienced. Total ambient mixing ratios varied between 3.6 and $(96.2 \pm 0.3) \mathrm{ppb}_{\mathrm{v}}$, with a variation between 3 and $(84.5 \pm 0.3) \mathrm{ppb}_{\mathrm{v}}$ inside the cuvette. The $50 \%$ of annual measurements were situated between 23.2 to $(57.1 \pm 0.3) \mathrm{ppb}_{\mathrm{v}}$. In general, spring values were $(7.4 \pm 0.3) \mathrm{ppb}_{\mathrm{v}}$ higher than the corresponding fourteen year averaged mixing ratios for this site. Contrariwise, the wet and cold summer resulted in average $(8.5 \pm 0.3) \mathrm{ppb}_{\mathrm{v}}$ lower ozone mixing ratios. Autumn values were in line with the previous years, indicating an anomaly of only $(1.0 \pm 0.3)$ $\mathrm{ppb}_{\mathrm{v}}$.

Assuming a solely dependency between ambient ozone stress and emission, an exponential relationship $\left(R^{2}=0.50\right.$; $R^{2}=0.38$ for linear) between ambient ozone mixing ratios and SQT emissions has been observed (Fig. 1b), with the ozone dependency (slope of the fitting) to be almost constant during the season. Measurements were conducted at the edge of the forest to the open area of the hill top, which means 

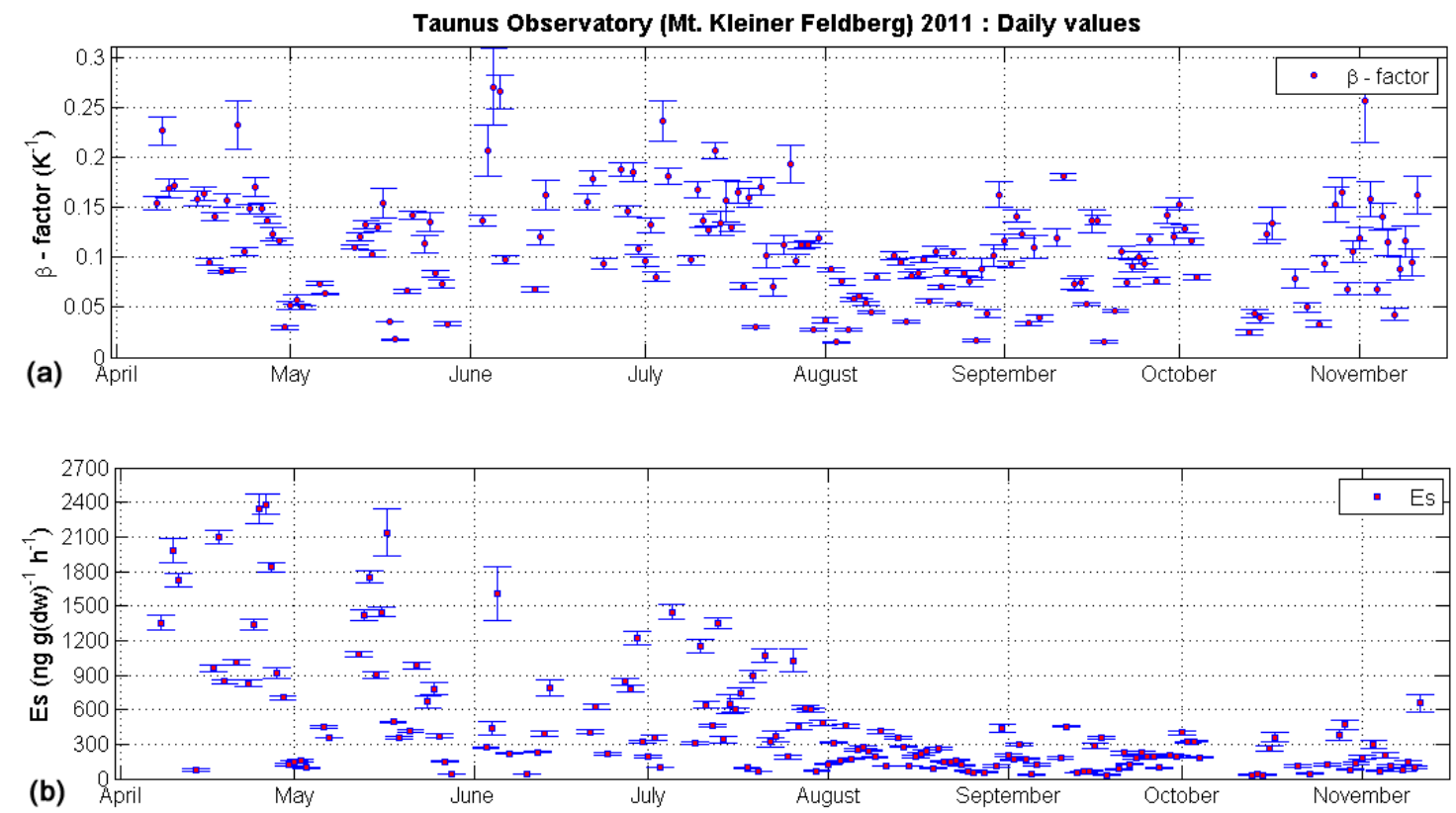

Fig. 2. $\beta$-factor (upper plot) and emission potential $E_{\mathrm{S}, T}$ (lower plot) derived from daily regression analysis.

that although measured at a height of five meters, the branch was facing the atmospheric ozone mixing ratio just as above the canopy. This excludes a notable reduction of ozone stress related emissions due to a lower height and a diminished ozone concentration within the vegetation layer (Jardine et al., 2011). For modelling studies this is a key aspect regarding the vertical profile with a maximum emission to be expected at the top of the forest. Wind coming from southern or southeastern directions transports anthropogenic ozone precursor gases from the Rhine-Main area, causing a steady replacement of the destroyed $\mathrm{O}_{3}$. Nevertheless, the decrease of $\mathrm{O}_{3}$ inside the cuvette during one close was substantial. This was partially caused by $\mathrm{NO}_{\mathrm{x}}$ and partially by biogenic VOC emissions. Both SQT emissions and ozone mixing ratios were peaking after noon and a direct relationship was observed during the complete measuring period.

Detailed equations of the exponential relationship between SQT emissions and ozone can be found in the caption of Fig. 1, while the reader is referred to Sect. 3.5 for a detailed formulation of the assumed relationship.

\subsubsection{Radiation effect}

In order to investigate possible light dependencies on SQT emissions, we separated our data in two individual categories (day and night) and plotted our results according to Eq. (2). Emission potential and temperature dependency were identical, within the uncertainty range, for both cases (Fig. 1c), indicating that radiation is not influencing SQT emissions. Emission potential at $30^{\circ} \mathrm{C}$ calculated for light conditions was $(365.1 \pm 77.1) \mathrm{ng} \mathrm{g}(\mathrm{dw})^{-1} \mathrm{~h}^{-1}$, while emission potential calculated for darkness was $(327 \pm 57.4) n g g(d w)^{-1} h^{-1}$. Similar values were calculated also for the $\beta$-factors considering the calculated uncertainties $\left(\beta_{\text {day }}=(0.12 \pm 0.02){ }^{\circ} \mathrm{C}^{-1}\right.$, $\left.\beta_{\text {night }}=(0.11 \pm 0.02)^{\circ} \mathrm{C}^{-1}\right)$.

\subsubsection{The effect of relative humidity}

Relative humidity (RH) was found to be anticorrelated with SQT emissions (Fig. 1d). However, the effect of this parameter on SQT emissions was significant only when RH was below $50 \%$. It is more likely that emissions were unaffected by mild RH conditions, but were affected substantially during extended drought periods (May). Only $7.6 \%$ of our data recorded RH values below $50 \%$. Under these conditions, SQT emissions rise substantially during spring and summer (Fig. 1d). Autumn conditions resulted in only few data points below this limit and, therefore, basal emission potential and RH dependency were substantially lower. In every case SQT emissions were suppressed when ambient RH conditions were high. The amount of released SQT almost never exceeded the value of $100 \mathrm{ng} g(\mathrm{dw})^{-1} \mathrm{~h}^{-1}$, when RH was maximum. This result indicates that small RH value may induce emissions, but only under severe drought conditions, while water stress could negatively affect plant responses.

\subsection{Daily emissions}

A clear mean daily cycle for SQT emissions has been observed. Emission generally peaked at midday (01:0004:00 p.m.) for all months, but the rise was starting two hours earlier (08:00 a.m.) for all the months before August. A vast amount of daily derived $\beta$-factors has been obtained from 


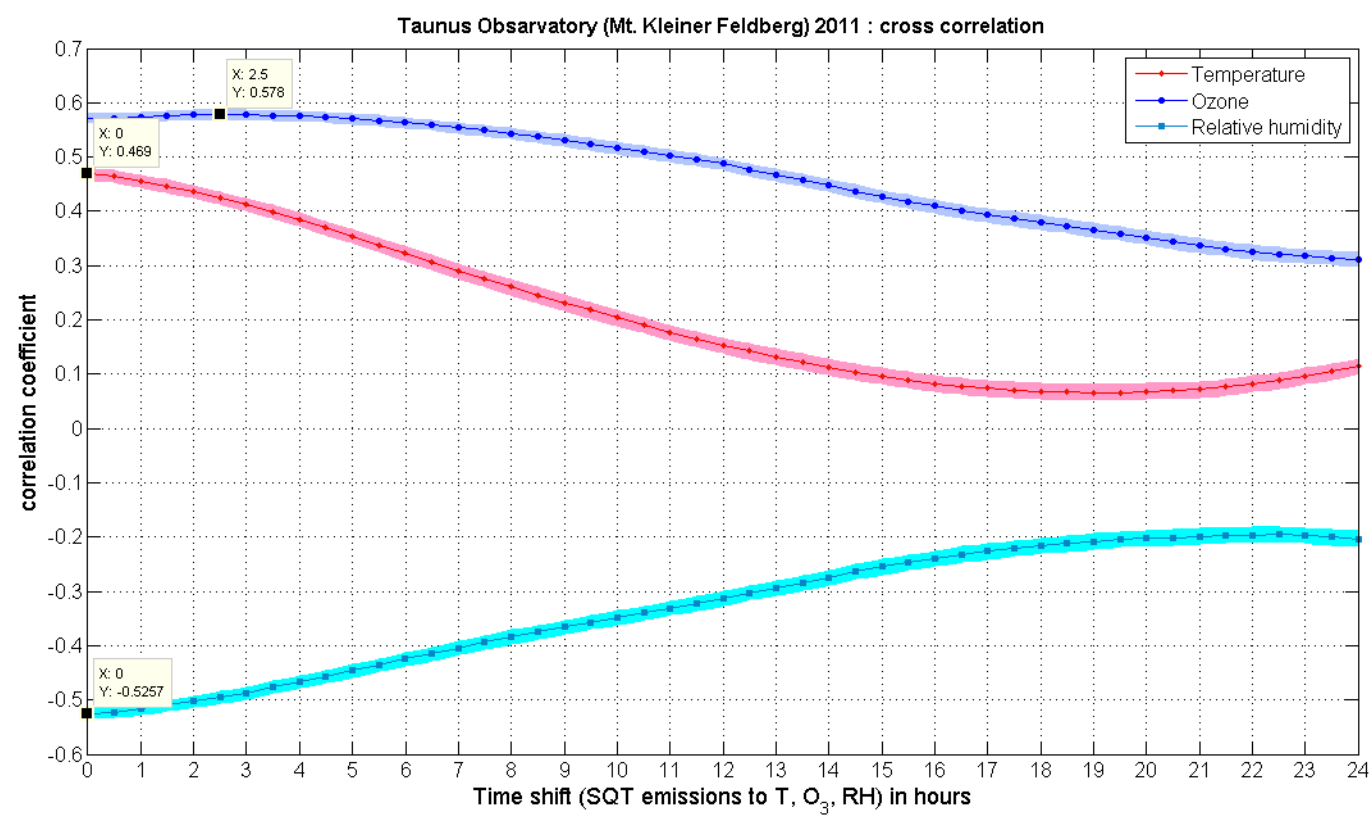

Fig. 3. Cross-correlation of SQT emission and temperature (red), ozone (blue) and relative humidity (cyan), with a time shift between the emissions and the individual stress factors.

regression analysis between enclosure temperature and SQT emissions (Fig. 2a). Calculated $\beta$-factors ranged for 0.02 to $0.27\left({ }^{\circ} \mathrm{C}^{-1}\right)$ with no distinct seasonal pattern. Highest values were observed during April and early summer, while the lowest ones were observed during the wet August (precipitation anomaly $=130-150 \%$, DWD). This can be an indication for the importance of water vapour and a detailed discussion about this issue can be found in Sect. 3.7. Autumn variations cover the whole spectrum, producing difficulties in understanding any possible seasonality of temperature driven emissions. During the growing period (26 April 2011 to 9 May 2011) $\beta$-factors ranged from 0.03 to $0.07^{\circ} \mathrm{C}^{-1}$, suggesting that temperature effect was weak, when new twigs were growing and other processes were taking place inside the leaves governing the emissions. The wide spectrum of $\beta$-factors indicates that temperature stress should not be considered as the single stress factor inducing SQT emissions, and that other environmental and biotic factors can amplify the temperature driven emissions.

Daily calculated emission potentials $E_{\mathrm{S}(T)}$ can be seen in Fig. 2b. Highest $E_{\mathrm{s}(T)}$ were observed during spring and an exponential decline was observed while moving towards the end of the year. Our results show a decline of SQT $E_{\mathrm{S}(T)}$ for every next month, apart from the transition from October to November. If SQT are stored inside some pools and used from the tree when required, the extremely dry November (historic record for Germany since 1900, DWD) can explain this rise in the basal emission rates. During the growing pe$\operatorname{riod} E_{\mathrm{S}(T)}$ was dramatically reduced as was the $\beta$-factor. An explanation for the reported low values could be that newly grown leaves have different SQT capacities and, therefore, react different to environmental factors until they become mature.

\subsection{Correlation coefficients}

The vast variations that have been extrapolated from the aforementioned regression analysis emphasise the need to investigate in detail the possible driving forces for SQT emissions. Figure 3 displays the three observed major driving forces and how they correlate with SQT emissions in time. Accounting in total 16200 emission data points, temperature showed a correlation of $(0.47 \pm 0.02)$ and $\mathrm{RH}$ an anticorrelation $-(0.53 \pm 0.01)$, indicating that RH can suppress SQT emissions.

Interestingly, one can observe a stronger dependency $(0.63 \pm 0.01)$ with ambient ozone concentrations, with the maximum correlation values $2-4 \mathrm{~h}$ (flat behaviour) before the emission start. This time frame can vary depending on the tree species and on the amount of ozone concentration that it is exposed. High ozone concentrations $\left(>60 \mathrm{ppb}_{\mathrm{v}}\right)$ resulted in maximum correlation coefficients $4-5 \mathrm{~h}$ before the emission, while low ozone concentrations resulted in poor correlation coefficients $(0.24 \pm 0.03)$ without a time delay. It might be that low ozone concentrations are still correlated with the emissions, because of their strong dependency on temperature. This indicates that ambient ozone concentrations can be substantially harmful for Norway spruce above a critical threshold. 


\section{Ozone regimes}

For investigating possible thresholds of the ozone concentrations, we separated our ozone data in ten different regimes with the same probability in between the limits of $10 \%$ (Gaussian distribution). Our aim was to investigate the strength of temperature and oxidative stress under different ozone conditions.

Correlation coefficients were calculated individually for each regime for both temperature and ozone concentrations (Fig. 4). In clear conditions, when ozone concentrations were below $(22 \pm 0.3) \mathrm{ppb}_{\mathrm{v}}$, temperature was much stronger correlated with SQT emissions. Nevertheless, the values were substantially changing, when we were taking account more polluted regimes. Temperature found to be the predominant driving force for the first four regimes (upper $\mathrm{O}_{3}$ regime limit $\left.=(36.6 \pm 0.3) \mathrm{ppb}_{\mathrm{v}}\right)$ with decreasing strength. On contrary correlation coefficients between SQT emissions and ozone were small for the first three regimes with the tendency to increase. For ozone concentrations between (36.6 and 52.2 \pm 0.3$) \mathrm{ppb}_{\mathrm{v}}$ the strength of these two driving forces was relative stable, with the indication that ozone is more important SQT emission driver than temperature. This spectrum of ozone volume mixing ratios is representative for the oxidative stress that the ecosystem at Mt. Kleiner Feldberg is experiencing ( $43.3 \%$ probability for the last $11 \mathrm{yr}$, HLUG), although common extremes during July and August were not achieved due to weather conditions in 2011. The last regime includes concentrations above $(58.5 \pm 0.3) \mathrm{ppbv}_{3}$ and one can clearly see a steep rise in ozone correlation coefficient. When ozone is substantially high, it displays the predominant driving force and triggers SQT emissions with the reported delay.

Ozone is produced in the troposphere by the tropospheric VOC-NOx-radiation cycle (Seinfeld and Pandis, 2006) via the conversion of $\mathrm{NO}$ to $\mathrm{NO}_{2}$ and the subsequent the photolysis of $\mathrm{NO}_{2}$. Since radiation and temperature are strongly coupled, both parameters show a dependency with ambient ozone concentrations. Figure 4 is also demonstrating the correlation coefficient between temperature and ambient ozone concentrations. In less polluted regimes the correlation is higher indicating the natural formation of ozone molecules without the subsequent destruction of ozone by elevated levels of $\mathrm{NO}_{\mathrm{x}}$. However, in more polluted regimes the given correlation is showing the tenancy to decline. This is attributed to the anthropogenic pollution arriving from the highly populated and industrialised Rhine-Main area. Therefore, the increased dependency shown for ozone in higher regimes, is not strongly associated with the temperature effect in SQT emissions.

In Fig. 5, we obtained the $\beta$-factors and emission potentials $\left(E_{\mathrm{s}, T}\right)$, derived from regression analysis between enclosure temperature and calculated emissions at each regime. For intercomparison reasons we also demonstrate the behaviour of total MT emissions, analysed with the same ap- proach. Figure 5a shows a different behaviour on $\beta$-factors for SQT and MT, respectively. For MT $\beta_{\mathrm{MT}}$ was relative constant through the complete ozone spectrum and close to the empirical value of $0.09^{\circ} \mathrm{C}^{-1}$ which is usually used in biogenic emission modelling studies (Guenther et al., 1995; Guenther et al., 2006). On contrary, $\beta_{\mathrm{SQT}}$ is showing a different behaviour at different regimes, with a possible threshold above $(36.6 \pm 3.9) \mathrm{ppb}_{\mathrm{v}}$. SQT $\beta$-factor is slightly higher than MTs one, but for ambient ozone mixing ratios fall inside the first two regimes (below $(28.2 \pm 0.3) \mathrm{ppb}_{\mathrm{v}}$ ). When oxidative stress was becoming stronger, the temperature dependency expressed by $\beta$-factor was dropping down to very small values. Interestingly, minimum $\beta_{\mathrm{SQT}}$ were calculated for the regimes that fall inside the range of ozone concentrations that have the highest probability to occur at this site.

Emission potentials showed a similar behaviour. $E_{s, \mathrm{MT}}$ was almost constant for the majority of ozone regimes, with the highest values to be observed at the edges of very clear and very polluted conditions. Regression tree analysis (Breiman et al., 1984) between ozone concentrations and MT emissions showed that MT are emitted in larger amounts when ambient ozone concentrations are above $(54 \pm 4)$ ppbv. Therefore, MT emissions could be also influenced by ambient ozone concentrations, but with a higher critical threshold. At the site of interest MT consist dominantly of MT reacting primary with $\mathrm{OH}$, but less with ozone, so they cannot be considered to be critical for ozone stress. On contrary, $E_{\mathrm{S}, \mathrm{SQT}}$ displayed a potential well along the ozone spectrum and the lowest values were once more obtained for the range with the most representative ozone concentrations for the ecosystem at this site. For the regimes above $47.7 \mathrm{ppb}_{\mathrm{v}}, E_{\mathrm{S}, \mathrm{SQT}}$ rise linearly with ozone, stressing out the importance of this environmental parameter as a driving force of SQT emissions.

\subsection{SQT emission algorithm}

Our results showed a clear correlation between SQT emissions and ambient ozone concentrations, suggesting that this environmental parameter should not be neglected in SQT emission model studies. We suggest a similar parameterisation with the one that is used for MT (Guenther et al., 1993) but with an additional term that includes the observed exponential relationship between ozone and SQT emissions:

$E_{\mathrm{SQT}, T}=E_{\mathrm{SQT}, T}+E_{\mathrm{SQT}, \mathrm{O}_{3}}$

$E_{\mathrm{SQT}, T}$ is the emission term that describes the effect of heat stress on SQT emissions

$E_{\mathrm{SQT}, T}=E_{\mathrm{s}, T} \cdot \exp (\beta \cdot(T-30))$

and $E_{\mathrm{SQT}, \mathrm{O}_{3}}$ is the additional term that is used to describe the oxidative stress:

$E_{\mathrm{SQT}, \mathrm{O}_{3}}=E_{\mathrm{s}, \mathrm{O}_{3}} \cdot \exp \left(\sigma \cdot\left(\left[\mathrm{O}_{3}\right]-40 \mathrm{ppb}_{\mathrm{v}}\right)\right)$ 


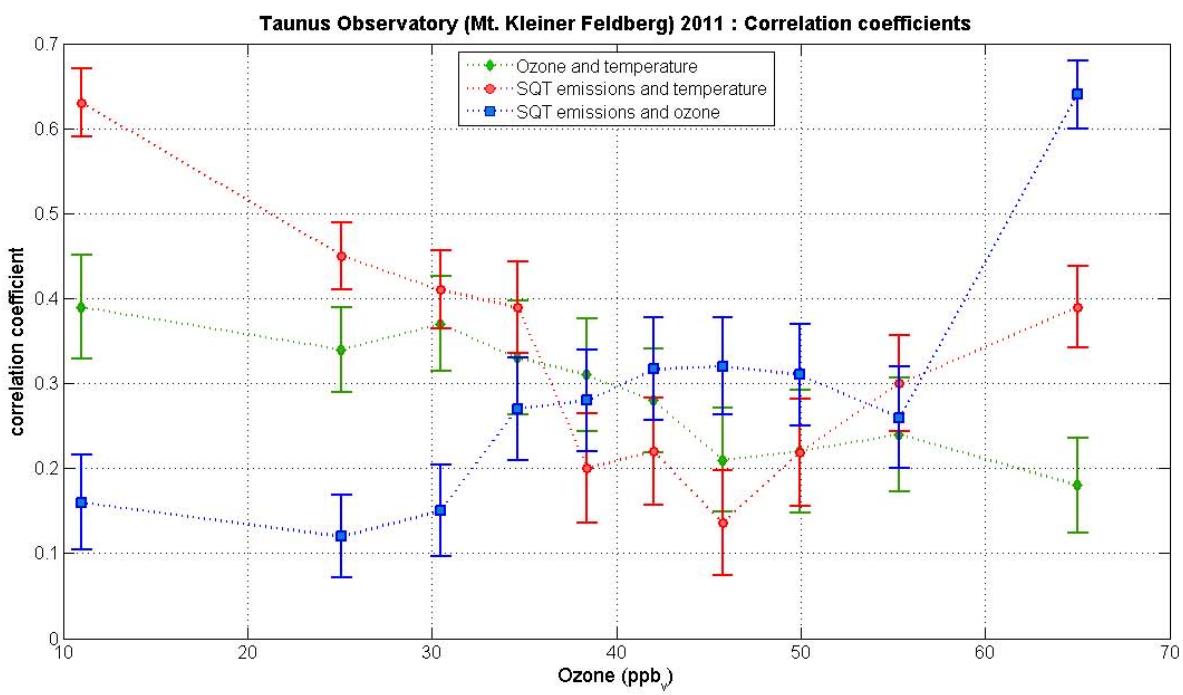

Fig. 4. Correlation coefficients for temperature and ozone calculated individually for ten different ozone regimes. In moderately or less polluted atmospheric conditions SQT emissions were better correlated with temperature, while in more polluted atmospheric conditions the emissions were better correlated with ambient ozone mixing ratios, indicating a critical threshold in the parameter that is driving the emissions. The smaller correlation between ambient ozone concentrations and temperature is observed in higher ozone regimes, indicating a stress due to ozone only not because of heat stress.
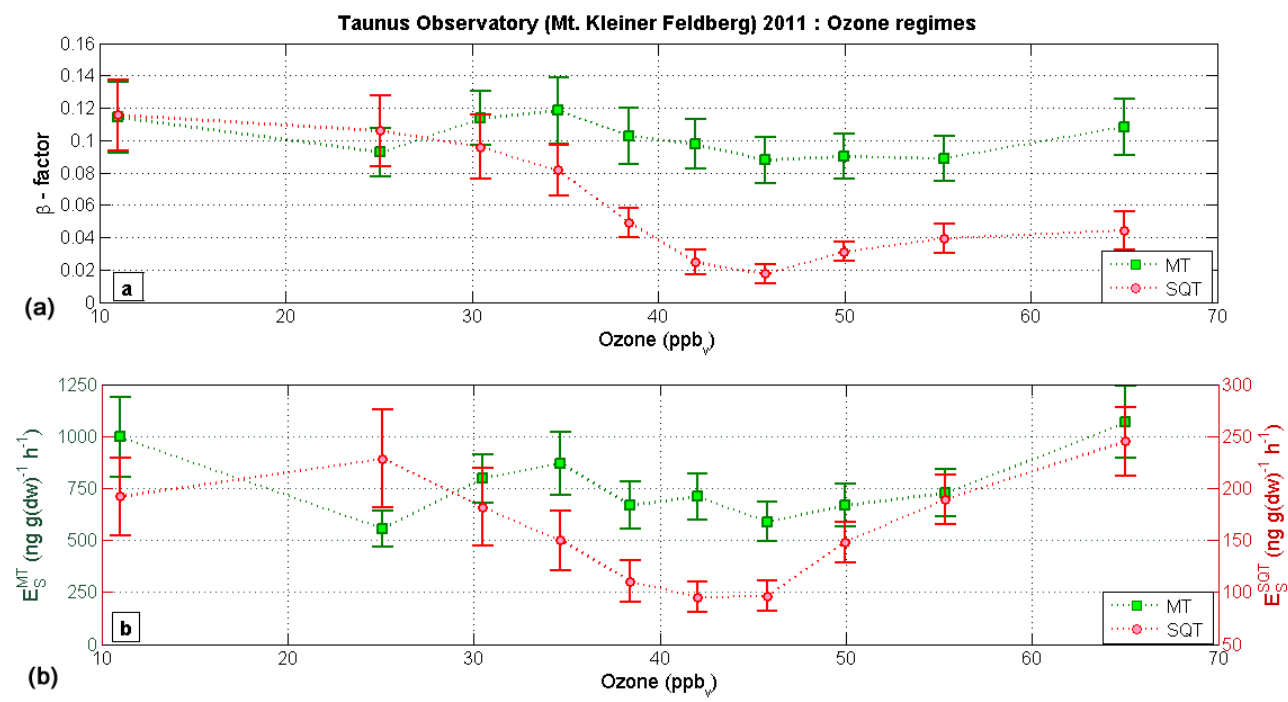

Fig. 5. $\beta$-factor (upper plot) and emission potential $E_{\mathrm{s}, T}$ (lower plot) for MT (green squares) and SQT (red cycles), derived from regression analysis for ten individual ozone regimes with the same probability. $\beta_{\mathrm{MT}}$ and emission potential $\left(E_{\mathrm{S}, \mathrm{MT}}\right)$ were almost constant along the complete ozone spectrum with no significant variation is visible. On contrary, $\beta_{\mathrm{SQT}}$ display smaller values after the fourth ozone regime. The respective emission potential $\left(E_{\mathrm{S}, \mathrm{SQT}}\right)$ is displayed as a dynamical well along the ozone spectrum, with the lowest values to be observed for the range with the most representative ozone concentrations for the site.

where $\beta\left({ }^{\circ} \mathrm{C}^{-1}\right)$ is an empirical coefficient called $\beta$ factor, $T$ is the temperature inside the cuvette (in ${ }^{\circ} \mathrm{C}$ ), $E_{\mathrm{s}, T}\left(\mathrm{ngg}(\mathrm{dw})^{-1} \mathrm{~h}^{-1}\right)$ is the emission potential at $T_{\mathrm{s}}=30^{\circ} \mathrm{C}$ (Guenther et al., 1993), $E_{\mathrm{s}, \mathrm{O}_{3}}\left(\mathrm{ngg}(\mathrm{dw})^{-1} \mathrm{~h}^{-1}\right)$ is the emission potential at $40 \mathrm{ppb}_{\mathrm{v}}$ mixing ratio of ozone, $\sigma\left(\mathrm{ppb}_{\mathrm{v}}^{-1}\right)$ is an empirical coefficient called $\sigma$-factor (sigma factor) and $\left[\mathrm{O}_{3}\right]$ is the ambient ozone mixing ratio in $\mathrm{ppb}_{\mathrm{v}}$. We chose to use the value of $40 \mathrm{ppb}_{\mathrm{v}} \mathrm{O}_{3}$ for the standard basal emission potential $E_{\mathrm{s}, \mathrm{O}_{3}}$ due to oxidative stress because of the critical threshold observed and presented at Sect. 3.4. Below this value, the second term of Eq. (3) has a minor contribution in total SQT emissions, but in higher concentrations, the importance of this pollutant as a driver of SQT emissions is magnified because of the exponential term in the equation. 


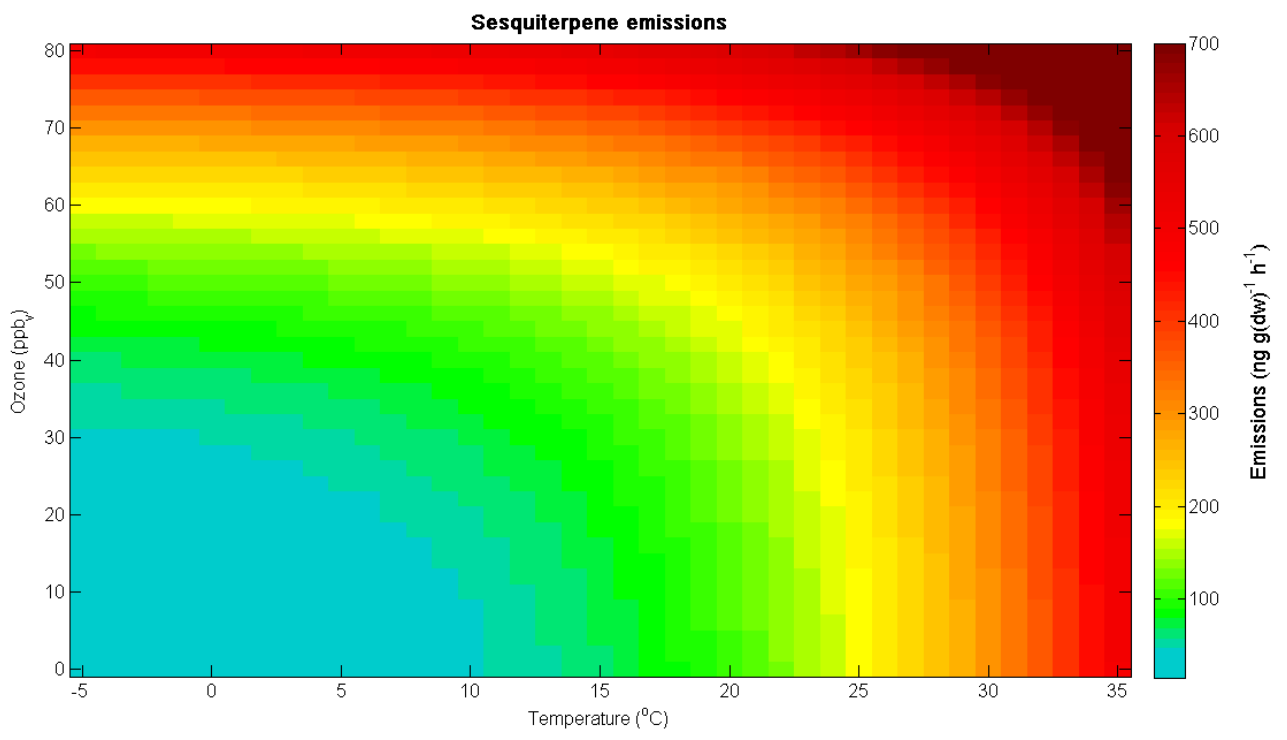

Fig. 6. Pattern of the derived SQT emissions, parameterised for the site of interest.

SQT emissions with representative values for the site of interest are illustrated in Fig. 6. The values applied in the equation are $E_{\mathrm{s}, T}=(347.2 \pm 70.4) \mathrm{ngg}(\mathrm{dw})^{-1} \mathrm{~h}^{-1}$, $\beta=(0.11 \pm 0.02)^{\circ} \mathrm{C}^{-1}, \quad E_{\mathrm{s}, \mathrm{O}_{3}}=(52.5 \pm 6.9) \quad \mathrm{ng}$ $\mathrm{g}(\mathrm{dw})^{-1} \mathrm{~h}^{-1}, \sigma=\left(0.05 \pm 0.01 \mathrm{ppb}_{\mathrm{v}}{ }^{-1}\right.$.

Thus, ozone stress has a minor impact in vegetation under not polluted conditions (Sects. 3.3 and 3.4) and, therefore, $E_{\mathrm{SQT}, \mathrm{O}_{3}}$ should be small in remote forests. Nevertheless, we observed (Fig. 5) that SQT emission responses to temperature can attenuate under higher ozone concentrations. This trend has already been hypothesized by Staudt et al. (2011), according to whom it is most likely that other environmental factors such as drought, ozone and $\mathrm{CO}_{2}$ concentrations can amplify or attenuate such alterations in the emission responses to temperature. An empirical formulation of SQT emissions, such the one that we suggest, cannot explain all the details of the emission profile of these compounds but it broadens our understanding in the tree responses under natural conditions.

\subsection{Intercomparison between emission algorithm and observations}

The algorithm that considers temperature as the only driving force (Eq. 2) was found to substantially underestimate SQT emissions during the year (Fig. 7). On contrary, when we consider additionally the oxidative stress, the fitting between the measured and calculated values improves considerably. Nevertheless, a so far neglected issue when modelling VOC emissions are the observed changes (Fig. 1, Sect. 3.1) at empirical coefficients ( $\beta$-, and $\sigma$-factor) and basal emission potentials $\left(E_{\mathrm{s}, T}, E_{\mathrm{s}, \mathrm{O}_{3}}\right)$ along the season. Using Eq. (3) with the aforementioned parameters individual for each season, the linear fit between observations and the suggested emission algorithm is close to $1: 1$ line. In any case the model overestimates the measured emissions, but not in a critical way. This deviation is most likely attributed to the effect of $\mathrm{RH}$, which was excluded from the algorithm even if a tentative effect on SQT emissions was observed (Fig. 1d).

Coupled with the presented linear fit between the measured SQT emissions and the modelled ones, a satisfactory fit was observed across the complete timeline of the measurements (Fig. 8). There are only two periods during the year, where a significant mismatch is apparent, while elsewhere the algorithm can efficiently capture SQT emissions. One period is during the growing season at the end of Aprilbeginning of May. Twigs length was measured continuously during this period and dry mass weight was derived from these measurements. New grown leaves have different pools and, therefore, different capabilities in emitting SQTs (Guenther et al., 2006). The second period that an overestimation of SQT emission was observed is located at the second half of August, but a clear explanation about this observation cannot be provided. We assume that, as Holopainen and Gershenzon (2010) stated at their review, that the co-occurrence of multiple stresses may significantly limit energy or nutrient supplies, and so it may not be possible for a plant to respond to every stress factor impinging on it at a single time. Additionally, SQT are usually stored before emissions and these storage pools are expected to decrease during the year. This applies especially at intense stress levels and only moderate production rates may expected thereafter. 


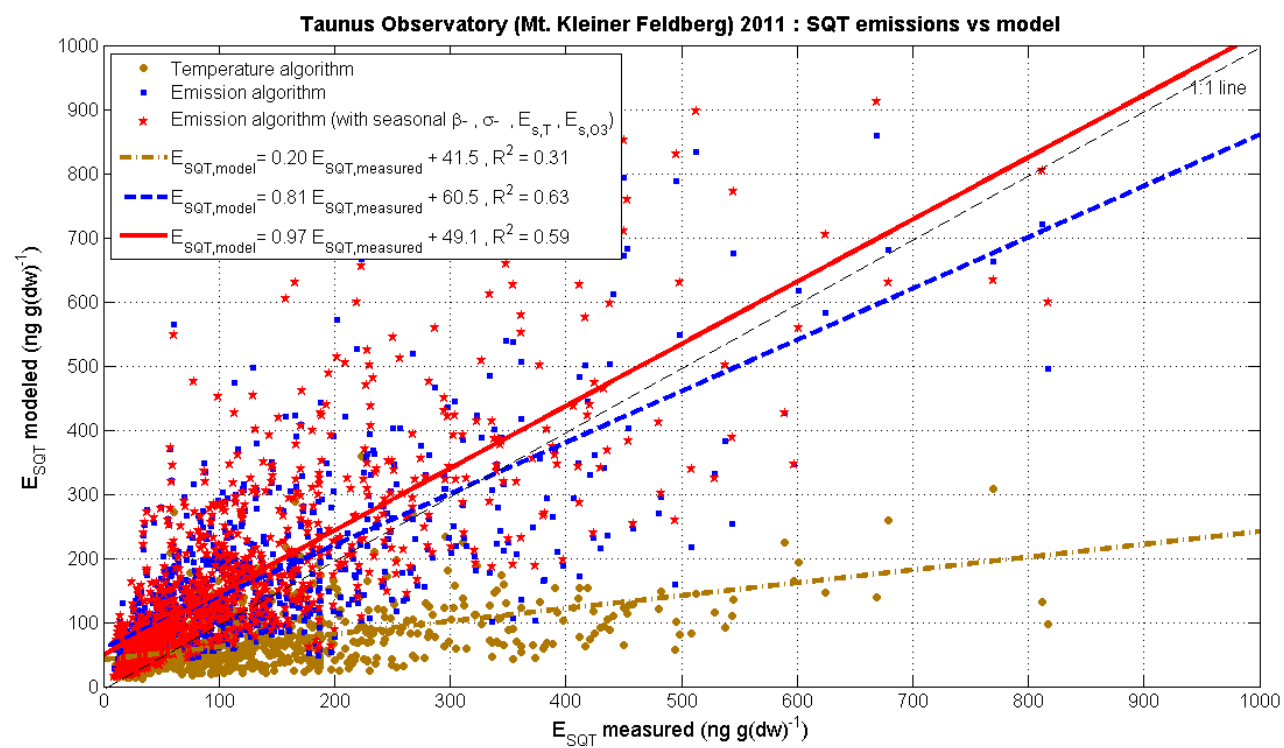

Fig. 7. Comparison between measured and calculated SQT emissions. An only temperature dependent algorithm substantially underestimates the measured emissions (gold dashed line). The addition of the ozone depended term (blue dashed line) is improving the fitting between measured and modelled emissions, while the best fit (red line) is observed when the seasonal $\beta$ and $\sigma$-factors and emission potentials ( $E_{\mathrm{s}, T}$, $E_{\mathrm{S}, \mathrm{O}_{3}}$ ) are considered in the algorithm.

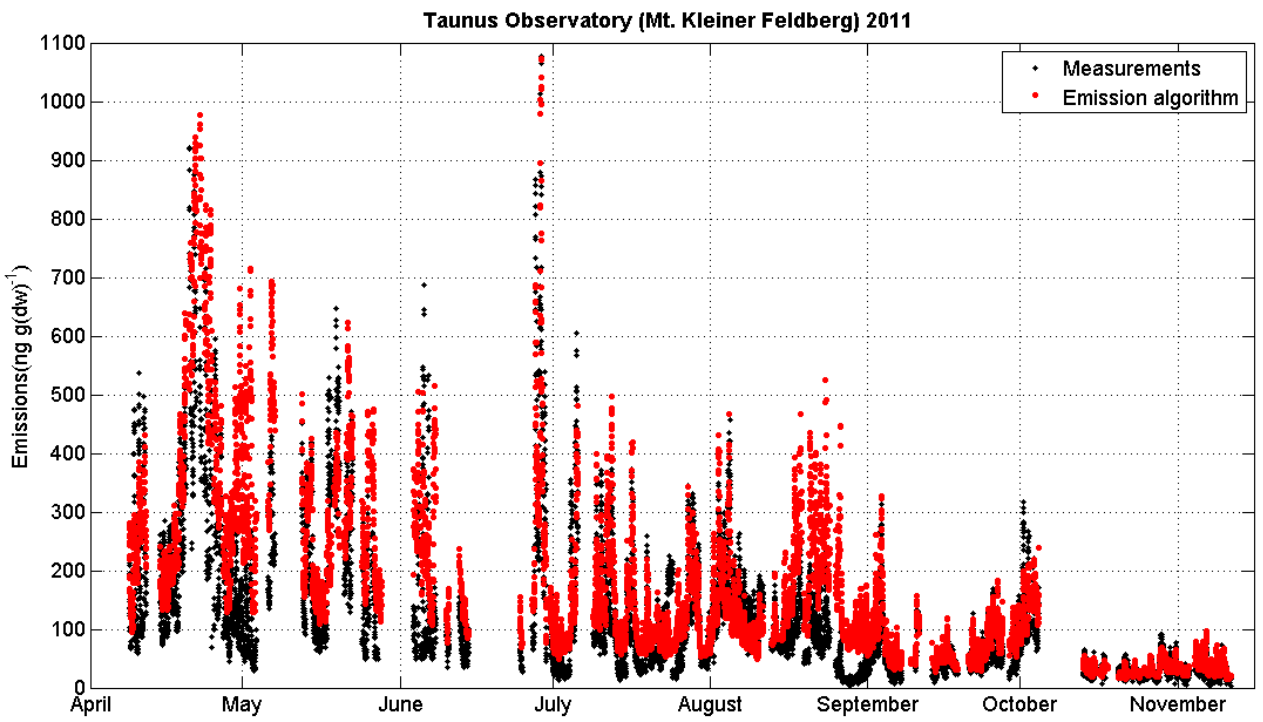

Fig. 8. Temporal pattern of the measurements compared with the new emission algorithm.

\subsection{The neglected role of relative humidity}

High RH was causing condensation and water films on needle surfaces. This resulted in reduced SQT emissions, indicating that the water film was acting in a protective way for ozone stress. This observation seems to explain the fact that our model overestimates SQT emissions under $100 \%$ of RH (Fig. 9). This could also explain the observed deviations presented in Fig. 7, despite the linearity between modelled and measured emissions. Our findings suggest that this parameter is influencing SQT emissions, but with a significant impact only under specific conditions. This might indicate different storage pools of sesquiterpenes within a single tree, which are used dependent on ambient conditions. Hence, further developments and field studies are essential in order to achieve a better understanding on SQT emissions from vegetation in ambient atmosphere. 


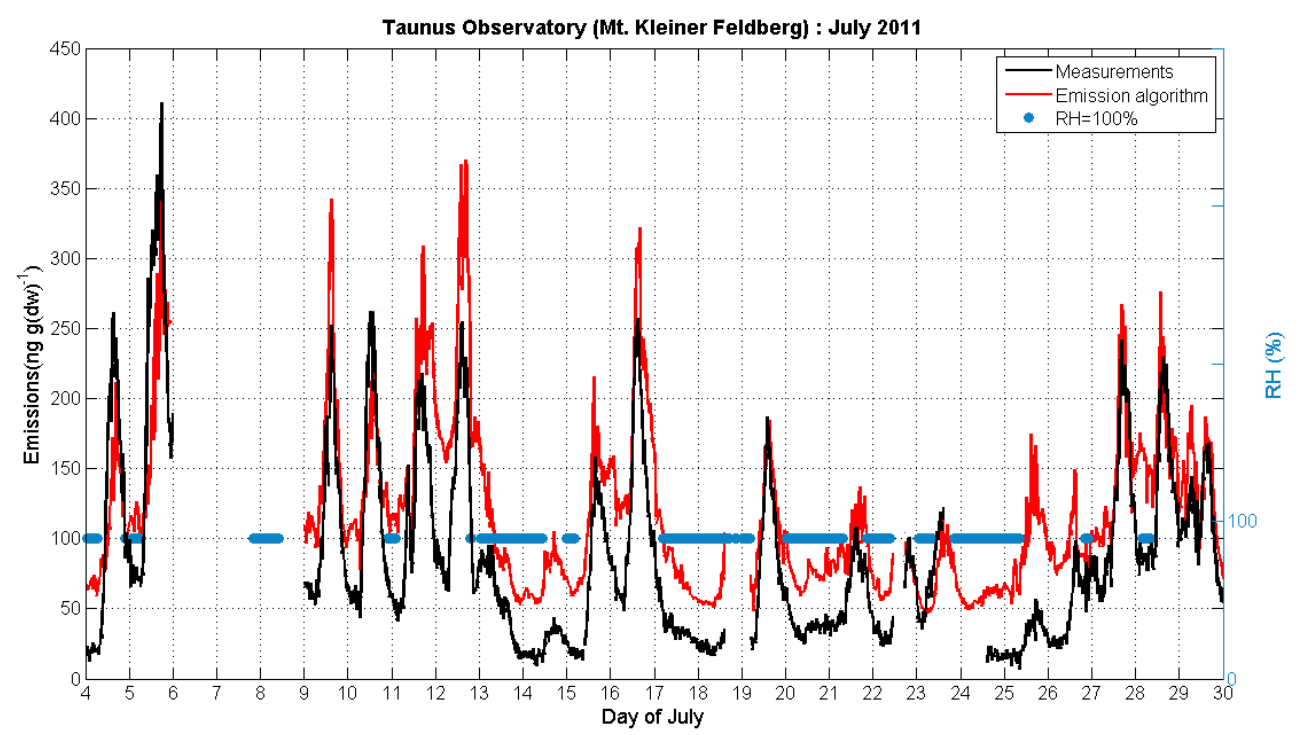

Fig. 9. Example of how RH can influence SQT emission rates. In case of $\mathrm{RH}=100 \%$, the algorithm fails, since the thin water layer created above the needle surface acts in protective way for the involved stresses.

\section{Discussion}

The relationship between plant stress and VOCs has been studied for several years in many ways, but stresses have usually been considered as single, independent factors. The review of Holopainen and Gershenzon (2010) has shown that the interaction of multiples stresses has great potential to alter VOC emission and that additive effect of stresses on VOC emissions might also be expected for combination of abiotic stresses, including high temperature and ozone, both of which induce higher VOC emission rates when applied singly. BVOC emissions are typically modelled with either temperature-dependent or temperature- and light-dependent algorithms (e.g., Guenther et al., 1995). Most emission models assume that the majority, if not all, of MTs are emitted as a function of temperature, but due to limited studies, SQT data are either eliminated from global models or vast assumptions have to be made about their emission drivers (Bouvier-Brown et al., 2008). Nevertheless, the reactivity of plant volatiles and their contribution in destroying ozone may have a significant impact on the interpretation of the role of such emissions (Jardine et al., 2011). If this compound is also emitted to protect the plant from elevated ozone concentrations, then we need to take this into account when trying to interpret the measurements. Total ozone fluxes in mid-latitude forests can be dominated by gas-phase chemistry and not by stomatal uptake (Fowler et al., 2001; Kurpius and Goldstein, 2003). Therefore, it is essential for the atmospheric chemistry to understand the correlations between the emitted SQT from vegetation and ambient ozone concentrations. We postulated an empirical parameterisation that can describe this relationship. However, the measurements were conducted using a single branch only and branch-to-branch variability depending on the height and the species is expected. Hence, a replication of this observation is important in order to draw final conclusions.

Our results showed a direct relationship between ambient ozone concentrations and SQT emissions with an observed delay in the correlation coefficients (Fig. 3). It is not the first time that a delay in ozone triggering emissions has been reported. Sharma et al. (1994) fumigated thaliana leaves and observed $3 \mathrm{~h}$ delay in the synthesis of phenylpropanoid compounds while Heiden at al. (1999) reported enhanced SQT concentrations $5 \mathrm{~h}$ after fumigating an ozone resistant variety of Nicotiana tabacum with $170 \mathrm{nmol} \mathrm{mol}^{-1} \mathrm{O}_{3}$. Hence, a delay in the ozone triggering SQT emissions needs to be considered in future studies.

Regression tree analysis showed that MT can also be influenced by ambient ozone concentrations. However, a clear exponential correlation similar with the one of SQT was not observed, while Es (MT) and $\beta_{\mathrm{MT}}$ were also relative stable along the different ozone regimes. The review of Peñuelas and Staudt (2010) is presenting a significant amount of studies that indicate a correlation between MT and ozone and, therefore, one should consider possible effects on MT emissions when studying the impact of ozone in vegetation.

Among the studies that have examined the light dependency of SQT emissions, there have been contrary findings, with evidence that some emissions are solely temperaturecontrolled while others are also affected by light (Duhl et al., 2008). Each of the studies that did not observe light dependencies in SQT emissions were conducted in field conditions under ambient light and temperature regimes and comes in line with our finding. As pointed out from Jardine 
et al. (2011) "SQTs are thought to mainly be produced in the cytosol via the MVA pathway, while MTs are thought to be mainly produced in chloroplasts via the MEP pathway". The direct connection to recently assimilated carbon may result in a strong light dependence on de novo MT production/emission, whereas de novo SQT production/emission may be more temperature dependent.

The controversial role of water stress in affecting the physiological response of plants when exposed to $\mathrm{O}_{3}$ has been reported by Vitale et al. (2008). Ribas et al. (2005) found that a severe water stress could negatively affect the $\mathrm{O}_{3}$ responses of Q. ilex, while more studies (Karlsson et al., 2002; Khan and Soja, 2003) emphasised the ability of water vapour to decrease the negative impact of $\mathrm{O}_{3}$ in several plant species. Even if we did not study the impact of water stress by measuring leaf water potential and stomatal conductance, we observed a similar reduction in the induced emissions under elevated RH. High RHs were causing condensation and water films on needle surfaces, acting in a protective way for the involved stresses and, therefore, this parameter should be also considered when studying SQT emissions.

\section{Conclusions}

In this study we found that SQT emission rates were clearly correlated with temperature, with an exponential function between temperature and emissions, similar to the one that is used for MT (Guenther et al., 1995). However, a similar link has been observed to ambient ozone mixing ratios, with even higher correlations coefficients than for temperature, when considering the annual dataset. A critical threshold above which ozone is the major driving force of SQT emissions was derived. We postulate a new parameterisation which includes both, i.e., the heat and the oxidative stress for a future application in global simulation models. Bäck et al. (2012) found that in contrary with MT, SQT emissions do not defer significantly between the investigated coniferous trees (Scots Pine) and, therefore, smaller uncertainties would be induced when applying the algorithm. However, more measurements are necessary in order to confirm the validly of this observation in other ecosystems. Finally, we observed the ability of water vapour to decrease the stress responses of the investigated tree under $100 \% \mathrm{RH}$ and, therefore, this parameter should not be neglected in any studies dealing with SQT emissions from vegetation.

Acknowledgements. The authors thank Jürgen Kesselmeier (MPI for Chemistry, Mainz, Germany) for providing the PAR sensors and HORIBA EUROPE GmbH Semiconductor Division for undertaking the needed calibrations for our ozone analyzer.

The service charges for this open access publication have been covered by the Max Planck Society.

Edited by: G. Wohlfahrt

\section{References}

Andreae, M. O. and Crutzen, P. J.: Atmospheric aerosols: Biogeochemical sources and role in atmospheric chemistry, Science, 276, 1052-1058, 1997.

Bäck, J., Aalto, J., Henriksson, M., Hakola, H., He, Q., and Boy, M.: Chemodiversity of a Scots pine stand and implications for terpene air concentrations, Biogeosciences, 9, 689-702, doi:10.5194/bg-9-689-2012, 2012.

Blake, R. S., Monks, P. S., and Ellis, A. M.: Proton-Transfer Reaction Mass Spectrometry, Chem. Rev., 109, 861-896, 2009.

Blande, J. D., Tiiva, P., Oksanen, E., and Holopainen, J. K.: Emission of herbivore-induced volatile terpenoids from two hybrid aspen (Populus tremula $\times$ tremuloides) clones under ambient and elevated ozone concentrations in the field, Glob. Change Biol., 13, 2538-2550, 2007.

Bonn, B. and Moortgat, G. K.: Sesquiterpene ozonolysis: Origin of atmospheric new particle formation from biogenic hydrocarbons, Geophys. Res. Lett., 30, 11, 1585, doi:10.1029/2003GL017000, 2003.

Bonn, B., Hirsikko, A., Hakola, H., Kurtén, T., Laakso, L., Boy, M., Dal Maso, M., Mäkelä, J. M., and Kulmala, M.: Ambient sesquiterpene concentration and its link to air ion measurements, Atmos. Chem. Phys., 7, 2893-2916, doi:10.5194/acp-7-28932007, 2007.

Bonn, B., Kulmala, M., Riipinen, I., et al.: How biogenic terpenes govern the correlation between sulfuric acid concentrations and new particle formation, J. Geophys. Res., 113, D12209, doi:10.1029/2007JD009327, 2008.

Bouvier-Brown, N. C., Goldstein, A. H., Gilman, J. B., Kuster, W. C., and de Gouw, J. A.: In-situ ambient quantification of monoterpenes, sesquiterpenes, and related oxygenated compounds during BEARPEX 2007: implications for gas- and particle-phase chemistry, Atmos. Chem. Phys., 9, 5505-5518, doi:10.5194/acp-9-5505-2009, 2009.

Boy, M., Karl, T., Turnipseed, A., Mauldin, R. L., Kosciuch, E., Greenberg, J., Rathbone, J., Smith, J., Held, A., Barsanti, K., Wehner, B., Bauer, S., Wiedensohler, A., Bonn, B., Kulmala, M., and Guenther, A.: New particle formation in the Front Range of the Colorado Rocky Mountains, Atmos. Chem. Phys., 8, 15771590, doi:10.5194/acp-8-1577-2008, 2008.

Brasseur, G., Kiehl, J., Muller, J., Schneider, T., Granier, C., Tie, X. X., and Hauglustaine, D.: Past and future changes in global tropospheric ozone: impact on radiative forcing, Geophys. Res. Lett., 25, 3807-3810, 1998.

Breiman, L., Friedman, J., Olshen, R., and Stone, C.: Classification and Regression Trees. Boca Raton, FL: CRC Press, 1984.

Carslaw, K. S., Boucher, O., Spracklen, D. V., Mann, G. W., Rae, J. G. L., Woodward, S., and Kulmala, M.: A review of natural aerosol interactions and feedbacks within the Earth system, Atmos. Chem. Phys., 10, 1701-1737, doi:10.5194/acp-10-17012010, 2010.

Crowley, J. N., Schuster, G., Pouvesle, N., Parchatka, U., Fischer, H., Bonn, B., Bingemer, H., and Lelieveld, J.: Nocturnal nitrogen oxides at a rural mountain-site in south-western Germany, Atmos. Chem. Phys., 10, 2795-2812, doi:10.5194/acp-10-27952010, 2010.

Demarcke, M., Amelynck, C., Schoon, N., Dhooghe, F., Van Langenhove, H., and Dewulf, J.: Laboratory studies in support of the detection of sesquiterpenes by proton-transfer-reaction- 
massspectrometry, Int. J. Mass Spectrom., 279, 156-162, 2009.

Dhooghe, F., Amelynck, C., Schoon, N., Debie, E., Bultinck, P., and Vanhaecke, F.: A selected ion flow tube study of the reactions of $\mathrm{H}_{3} \mathrm{O}^{+}, \mathrm{NO}^{+}$and $\mathrm{O}_{2}^{-}$with a series of sesquiterpenes, Int. J. Mass Spectrom., 272, 137-148, 2008.

Duhl, T. R., Helmig, D., and Guenther, A.: Sesquiterpene emissions from vegetation: a review, Biogeosciences, 5, 761-777, doi:10.5194/bg-5-761-2008, 2008.

Ezra, D., Jasper, J., Rogers, T., Knighton, B., Grimsrud, E., and Strobel, G.: Proton transfer reaction mass spectrometry as a technique to measure volatile emissions of Muscodor albus, Plant Sci., 166, 1471-1477, 2004.

Fares, A., Goldstein, A., and Loreto, F.: Determinants of ozone fluxes and metrics for ozone risk assessment in plants, J. Exp. Bot., 61, 629-633, 2010.

Fehsenfeld, F., Calvert, J., Fall, R., Goldman, P., Guenther, A. B., Hewitt, C. N., Lamb, B., Liu, S., Trainer, M., Westberg, H., and Zimmerman, P.: Emissions of volatile organic compounds from vegetation and the implications for atmospheric chemistry, Global Biogeochem. Cy., 6, 389-430, 1992.

Filella, I., Wilkinson, M. J., Llusiá, J., Hewitt, C. N., and Penñelas, J.: Volatile organic compounds emissions in Norway spruce (Picea abies) in response to temperature changes, Physiol. Plantarum, 2007.

Fowler, D. B., Breton, G., Limin, A. E., Mahfoozi, S., and Sarhan, F.: Photoperiod and Temperature Interactions Regulate LowTemperature Induced Gene Expression in Barley, Plant Physiol., 127, 1676-1681, 2001.

Fuentes, J. D., Lerdau, M., Atkinson, R., Baldocchi, D., Bottenheim, J. W., Ciccioli, P., Lamb, B., Geron, C., Gu, L., Guenther, A., Sharkey, T. D., and Stockwell, W.: Biogenic hydrocarbons in the atmospheric boundary layer: A review, B. Am. Meteorol. Soc., 81, 1537-1575, 2000.

Guenther, A. B., Zimmerman, P. R., Harley, P. C., Monson, R. K., and Fall, R.: Isoprene and monoterpene emission rate variability: Model evaluation and sensitivity analyses, J. Geophys. Res., 98, 12609-12617, 1993.

Guenther, A., Hewitt, C. N., Erickson, D., Fall, R., Geron, C., Graedel, T., Harley, P., Klinger, L., Lerdau, M., McKay, W. A., Pierce, T., Scholes, B., Steinbrecher, R., Tallamraju, R., Taylor, T., and Zimmerman, P.: A global model of natural volatile organic compound emissions, J. Geophys. Res., 100, 8873-8892, 1995.

Guenther, A., Geron, C., Pierce, T., Lamb, B., Harley, P., and Fall, R.: Natural emissions of non-methane volatile organic compounds, carbon monoxide, and oxides of nitrogen from North America, Atmos. Environ., 34, 2205-2230, 2000.

Guenther, A., Karl, T., Harley, P., Wiedinmyer, C., Palmer, P. I., and Geron, C.: Estimates of global terrestrial isoprene emissions using MEGAN (Model of Emissions of Gases and Aerosols from Nature), Atmos. Chem. Phys., 6, 3181-3210, doi:10.5194/acp-63181-2006, 2006.

Guderian, R. (Ed.): Effects of photochemical oxidants on plants. Air pollution by photochemical oxidants, Springer, Berlin, 129-333, 1985.

Hakola, H., Tarvainen, V., Bäck, J., Ranta, H., Bonn, B., Rinne, J., and Kulmala, M.: Seasonal variation of mono- and sesquiterpene emission rates of Scots pine, Biogeosciences, 3, 93-101, doi:10.5194/bg-3-93-2006, 2006.
Heated stainless steel tube for ozone removal in the ambient air measurements of mono- and sesquiterpenes, Atmos. Environ., 57, 35-40, doi:10.1016/j.atmosenv.2012.04.019, 2012.

Hellén, H., Kuronen P., and Hakola H.: Heated stainless steel tube for ozone removal in the ambient air measurements of mono- and sesquiterpenes, Atmos. Environ., 57, 35-40, doi:10.1016/j.atmosenv.2012.04.019, 2012.

Helmig, D., Revermann, T., Pollmann, J., Kaltschmidt, O., Jiménez Hernández, A., Bocquet, F., and David, D.: Calibration system and analytical considerations for quantitative Sesquiterpene measurements in air, J. Chromatogr. A., 1002, 193-211, 2003.

Helmig, D., Ortega, J., Guenther, A., Herrick, J. D., and Geron, C.: Sesquiterpene emission from loblolly pine and their potential contribution to biogenic aerosol formation in the Southeastern US, Atmos. Environ., 40, 4150-4157, 2006.

Helmig, D., Ortega, J., Duhl, T., Tanner, D., Guenther, A., Harley, P., Wiedinmyer, C., Milford, J., and Sakulyanontvittaya, T.: Sesquiterpene emissions from pine trees - identifications, emission rates and flux estimates for the contiguous United States, Environ. Sci. Technol., 41, 1545-1553, 2007.

Hewitt, C., Kok, G., and Fall, R.: Hydroperoxides in plants exposed to ozone mediate air pollution damage to alkene emitters, Nature, 344, 56-58, 1990.

Heiden, A. C. , Hoffman, T., Kahl, J., Kley, D., Klockow, D., Langebartels, C., Mehlhorn, H., Sandermann, H. Jr., Schraudner, M., Schuh G., and Wildt, J.: Emission of volatile organic compounds from ozone-exposed plants, Ecol. Appl., 9, 1160-1167, 1999.

Hoffmann, T., Odum, J. R., Bowman, F., Collins, D., Klockow, D., Flagan, R. C., and Seinfeld, J. H.: Formation of organic aerosols from the oxidation of biogenic hydrocarbons, J. Atmos. Chem., 26, 189-222, 1997.

Holopainen, J. K. and Gershenzon, J.: Multiple stress factors and the emission of plant VOCs, Trends Plant Sci., 15, 176-184, 2010.

Jaoui, M., Leungsakul, S., and Kamens, R. M.: Gas and particle products distribution from the reaction of -caryophyllene with ozone, J. Atmos. Chem., 45, 261-287, 2003.

Jardine, K., Serrano, A. Y., Arneth, A., Abrell, L., Jardine, A., van Haren, J., Artaxo, P., Rizzo, L. V., Ishida, F. Y., Karl, T., Kesselmeier, J., Saleska, S., and Huxman, T.: Within-canopy sesquiterpene ozonolysis in Amazonia, J. Geophys. Res.-Atmos., 116, D19301, doi:10.1029/2011JD016243, 2011.

Jardine K., Monson R., Abrell L., Saleska S., Arneth A., Jardine A., Ishida F. C., Serrano A. M. Y., Artaxo P., Karl T., Fares S., Goldstein A., Loreto F., and Huxman T.: Within-plant isoprene oxidation confirmed by direct emissions of oxidation products methyl vinyl ketone and methacrolein, Glob. Change Biol., 18, 973-984, 2012.

Karlsson, P. E., Medin, E. L., Selldén, G., Wallin, G., Ottosson, S., Pleijel, H., and Skärby, L.: Impact of ozone and reduced water supply on the biomass accumulation of Norway spruce saplings. Environ. Pollut., 119, 237-244, 2002.

Karnosky, D. F., Skelly, J. M., Percy, K. E., and Chappelka, A. H.: Perspectives regarding 50 years of research on effects of tropospheric ozone air pollution on US forests, Environ. Poll., 147, 489-506, 2007.

Kesselmeier, J. and Staudt, M.: Biogenic volatile organic compounds (VOC): An overview on emission, physiology and ecology, J. Atmos. Chem., 33, 23-88, 1999. 
Khan, S. and Soja, G.: Yield responses of wheat to ozone exposure as modified by drought-induced differences in ozone uptake, Water Air Soil Pollut., 147, 299-315, 2003.

Kim, S., Karl, T., Helmig, D., Daly, R., Rasmussen, R., and Guenther, A.: Measurement of atmospheric sesquiterpenes by proton transfer reaction-mass spectrometry (PTR-MS), Atmos. Meas. Tech., 2, 99-112, doi:10.5194/amt-2-99-2009, 2009.

Kim, S., Karl, T., Guenther, A., Tyndall, G., Orlando, J., Harley, P., Rasmussen, R., and Apel, E.: Emissions and ambient distributions of Biogenic Volatile Organic Compounds (BVOC) in a ponderosa pine ecosystem: interpretation of PTR-MS mass spectra, Atmos. Chem. Phys., 10, 1759-1771, doi:10.5194/acp-101759-2010, 2010.

Kulmala, M., Suni, T., Lehtinen, K. E. J., Dal Maso, M., Boy, M., Reissell, A., Rannik, Ü., Aalto, P., Keronen, P., Hakola, H., Bäck, J., Hoffmann, T., Vesala, T., and Hari, P.: A new feedback mechanism linking forests, aerosols, and climate, Atmos. Chem. Phys., 4, 557-562, doi:10.5194/acp-4-557-2004, 2004.

Kurpius, M. R. and Goldstein, A. H.: Gas-phase chemistry dominates $\mathrm{O} 3$ loss to a forest, implying a source of aerosols and hydroxyl radicals to the atmosphere, Geophys. Res. Lett., 30, 1371, doi:10.1029/2002GL016785, 2003.

Lee, A., Goldstein, A. H., Keywood, M. D., Gao, S., Varutbangkul, V., Bahreini, R., Ng, N. L., Flagan, R. C., and Seinfeld, J. H.: Gas-phase products and secondary aerosol yields from the ozonolysis of ten different terpenes, J. Geophys. Res., 111, D07302, doi:10.1029/2005JD006437, 2006.

Loreto, F. and Fares, S.: Is ozone flux inside leaves only a damage indicator? Clues from volatile isoprenoid studies, Plant Physiol., 143, 1096-1100, 2007.

Loreto, F. and Schnitzler, J.-P.: Abiotic stresses and induced BVOCs, Trends Plant Sci., 15, 154-166, 2010.

Loreto, F., Mannozzi, M., Maris, C., Nascetti, P., Ferranti, F., and Pasqualini, S.: Ozone quenching properties of isoprene and its antioxidant role in leaves, Plant Physiol. 126, 993-1000, 2001.

Loreto, F., Pinelli, P., Manes, F., and Kollist, H.: Impact of ozone on monoterpene emissions and evidences for an isoprene-like antioxidant action of monoterpenes emitted by Quercus ilex (L.) leaves, Tree Physiol., 24, 361-367, 2004.

Münz, J.: Entwicklung einer Thermodesorptionseinheit für die GC/MS zur Bestimmung hochreaktiver, biogener Kohlenwasserstoffe und deren Anwendung im Rahmen von Labor- und Feldstudien, PhD thesis, Mainz University, Mainz, 2010.

Niinemets, Ü., Loreto, F., and Reichstein, M.: Physiological and physico-chemical controls on foliar volatile organic compound emissions, Trends Plant Sci., 9, 180-186, 2004.

Niinemets, Ü., Kuhn, U., Harley, P. C., Staudt, M., Arneth, A., Cescatti, A., Ciccioli, P., Copolovici, L., Geron, C., Guenther, A., Kesselmeier, J, Lerdau, M. T., Monson, R. K., and Peñuelas, J.: Estimations of isoprenoid emission capacity from enclosure studies: measurements, data processing, quality and standardized measurement protocols, Biogeosciences, 8, 2209-2246, doi:10.5194/bg-8-2209-2011, 2011.

Parrish, D. D., Millet, D. B., and Goldstein, A. H.: Increasing ozone in marine boundary layer inflow at the west coasts of North America and Europe, Atmos. Chem. Phys., 9, 1303-1323, doi:10.5194/acp-9-1303-2009, 2009.
Peñuelas, J. and Staudt, M.: BVOCs and global change, Trends Plant Sci., 15, 133-144, 2010.

Ribas, A., Peñuelas, J., Elvira, S., and Gimeno, B. S.: Contrasting effects of ozone under different water supplies in two Mediterranean tree species, Atmos. Environ., 39, 685-693, 2005.

Ruuskanen, T. M., Kolari, P., Bäck, J., Kulmala, M., Rinne, J., Hakola, H., Taipale, R., Raivonen, M., Altimir, N., and Hari, P.: On-line field measurements of monoterpene emissions from Scots pine by proton transfer reaction - mass spectrometry, Boreal Environ. Res., 10, 553-567, 2005.

Seinfeld, J. H. and Pandis, S. N.: Atmospheric Chemistry and Physics: From Air Pollution to Climate Change, 2nd ed., John Wiley \& Sons: New York, USA, 2006.

Sharma, Y. and Davis, K.: Ozone-induced expression of stressrelated genes in Arabidopsis thaliana, Plant Physiol., 105, 108996, 1994.

Staudt, M. and Lhoutellier, L.: Monoterpene and sesquiterpene emissions from Quercus coccifera exhibit interacting responses to light and temperature, Biogeosciences, 8, 2757-2771, doi:10.5194/bg-8-2757-2011, 2011.

Shu, Y. and Atkinson, R.: Rate constants for the gas-phase reactions of $\mathrm{O}_{3}$ with a series of terpenes and $\mathrm{OH}$ radical formation from the $\mathrm{O}_{3}$ reactions with sesquiterpenes at $296 \mathrm{~K}$, Int. J. Chem. Kinet., 26, 1193-1205, 1994.

Tarvainen, V., Hakola, H., Hellén, H., Bäck, J., Hari, P., and Kulmala, M.: Temperature and light dependence of the VOC emissions of Scots pine, Atmos. Chem. Phys., 5, 989-998, doi:10.5194/acp-5-989-2005, 2005.

Tarvainen, V., Hakola, H., Rinne, J., Hellén, H., and Haapanala, S.: Towards a comprehensive emission inventory from boreal ecosystems, Tellus, 59B, 526-534, 2007.

Vickers, C. E., Gershenzon, J., Lerdau, M. T., and Loreto, F.: A unified mechanism of action for volatile isoprenoids in plant abiotic stress, Nat. Chem. Biol., 5, 283-291,2009.

Vitale M., Salvatori E., Loreto F., Fares S., and Manes, F.: Physiological responses of Quercus ilex leaves to water stress and acute ozone exposure under controlled conditions, Water Air Soil Pollut., 189, 113-25, 2008.

Vuorinen, T., Nerg, A. M., and Holopainen, J. K.: Ozone exposure triggers the emission of herbivore-induced plant volatiles, but does not disturb tritrophic signaling, Environ. Pollut., 131, 305-311, 2004.

Vuorinen, T., Nerg, A.-M., Vapaavuori, E., and Holopainen, J. K.: Emission of volatile organic compounds from two silver birch (Betula pendula Roth) clones grown under ambient and elevated $\mathrm{CO}_{2}$ and different $\mathrm{O}_{3}$ concentrations, Atmos. Environ., 39, 1185-1197, 2005.

Vollenweider, P. and Gunthardt-Goerg, M. S.: Diagnosis of abiotic and biotic stress factors using the visible symptoms in foliage, Environ. Pollut., 137, 455-465, 2005.

Zhao, J. and Zhang, R. Y.: Proton transfer reaction rate constants between hydronium ion $\left(\mathrm{H}_{3} \mathrm{O}^{+}\right)$and volatile organic compounds, Atmos. Environ., 38, 2177-2185, 2004. 